Florida International University FIU Digital Commons

\title{
Aspects of the transplantation, storage and maintenance of corals (Montastraea Faveolata, Acropora Cervicornis and A. Palmata)
}

Lillian C. Becker

Florida International University

DOI: $10.25148 /$ etd.FI14050466

Follow this and additional works at: https://digitalcommons.fiu.edu/etd

Part of the Biology Commons

\section{Recommended Citation}

Becker, Lillian C., "Aspects of the transplantation, storage and maintenance of corals (Montastraea Faveolata, Acropora Cervicornis and A. Palmata)" (2000). FIU Electronic Theses and Dissertations. 1467.

https://digitalcommons.fiu.edu/etd/1467 
FLORIDA INTERNATIONAL UNIVERSITY

Miami, Florida

\begin{abstract}
ASPECTS OF THE TRANSPLANTATION, STORAGE AND
MAINTENANCE OF CORALS (MONTASTRAEA

FAVEOLATA, ACROPORA CERVICORNIS AND A. PALMATA)

FOR THE PURPOSES OF RESTORATION
\end{abstract}

\author{
A thesis submitted in partial fulfillment of the \\ requirements for the degree of \\ MASTER OF SCIENCE \\ in \\ BIOLOGY \\ by \\ Lillian C. Becker
}

2002 
To: Dean Arthur W. Herriott

College of Arts and Sciences

This thesis, written by Lillian C. Becker, and entitled Aspects of the Transplantation, Storage and Maintenance of Corals (Montastraea Faveolata, Acropora Cervicornis and A. Palmata) for the Purposes of Restoration, having been approved in respect to style and intellectual content is referred to you for judgment.

We have read this thesis and recommend that it be approved.
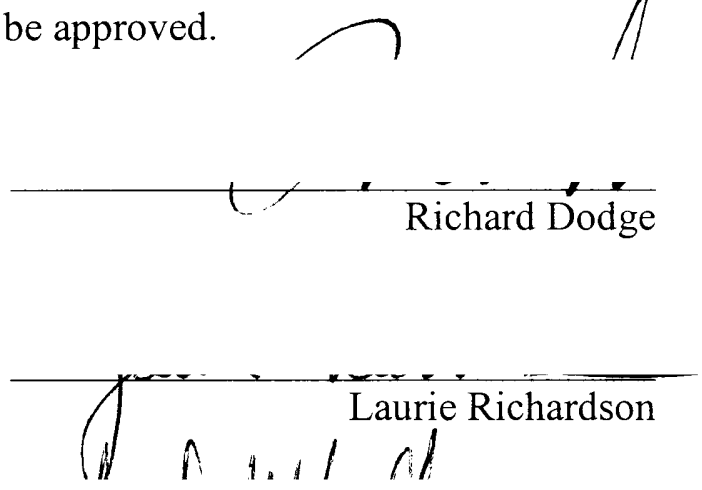

Erich Mueller, Co-Major Professor

Walter Goldberg, Co-Major Professor

Date of Defense: July 24, 2000

The thesis of Lillian C. Becker is approved.

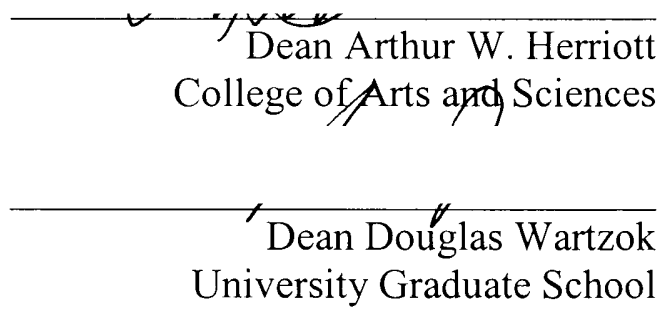

Florida International University, 2002 


\section{DEDICATION}

I dedicate this thesis to all those people along the way who saw more in me than I saw in myself. This includes teachers, coworker, friends and colleagues who held high expectations while nudging (occasionally shoving) me with love and encouragement. I would never have achieved this much without them. The most important of these wonderful people is Thomas Alfred Howe, without whom I never would have returned to school and rediscovered what I am capable of. 


\section{ACKNOWLEDGMENTS}

I would like to thank my major professors, Dr. Erich Mueller and Dr. Walter Goldberg, for working with me under unusual circumstances. I would also like to thank them and the other members of my committee, Dr. Laurie Richardson and Dr. Richard Dodge, for all of their time, patience, support and comments.

I would like to thank: Eric Annis, Ive Barreiros, Bert Bauxbum, Mike Brittson, Rob Carter, Clay Cook, Richard Dodge, Pam Eng, Elizabeth Glynn, Walter Goldberg, Pat and Steve Gooch, Billy Gotthart, Justin Gwynn, Ben Haskell, Chris Higham, Paulette Johnson, Cindy Marshall, Lauri MacLaughlin, Chad McNutt, Diane Mueller, John Nazarro, Leah Ashley Ostenburg, Michelle Ostenburg, Esther Peters, Susan Phillips, Laurie Richardson, Debbie Santavy, Nicole Sheppard, Joe Silvia, Jamie Vernacchio, Shay Viehman, Holley Voegtle, Sharon Wada, Julianna Weir, and Robert Weisman for their contributions large and small. A very special thanks goes to Tim Howe.

Funding and logistical support was received from: National Science Foundation (DEB-9596271), Florida Keys National Marine Sanctuary [FKNMS-1797, FKNMS(LR)-09-96], Florida Marine Research Institute, Caribbean Marine

Research Center, South Florida Tropical Biological Program, Florida International University Graduate Student Association, U.S. EPA, and M. Ostenburg. 


\author{
ABSTRACT OF THE THESIS \\ ASPECTS OF THE TRANSPLANTATION, STORAGE AND \\ MAINTAINANCE OF CORALS (MONTASTRAEA \\ FAVEOLATA, ACROPORA CERVICORNIS AND A. PALMATA) \\ FOR THE PURPOSES OF RESTORATION \\ by \\ Lillian C. Becker \\ Florida International University, 2002 \\ Miami, Florida \\ Professor Erich Mueller, Co-Major Professor \\ Professor Walter Goldberg, Co-Major Professor
}

The purpose of this study is to explore aspects of coral transplantation for restoration. Montastraea faveolata cores of 2.54 and $5.0 \mathrm{~cm}$ were stored in aquaria, on an array and on the substrate. Survival on the array and substrate were $100 \%$ for 12 and 11 months respectively. Branches of Acropora cervicornis had $75.0 \%$ survival on the substrate and $91.7 \%$ on the array. Disease caused mortality for the $A$. cervicornis and the $2.54 \mathrm{~cm}$ cores in the aquaria but not for the $5.0 \mathrm{~cm}$ cores. Growth was significantly higher for A. cervicornis and A. palmata branches stored on an array than in an open seawater system. The storage type affected growth patterns of both species. $M$. faveolata fed three times/week increased in surface area significantly more than those fed once and twice/week. Corals fed once per week significantly increased their polyp density. Corals had intermittent respiration while under sub-aerial conditions. 
I. INTRODUCTION AND LITERATURE SEARCH................................

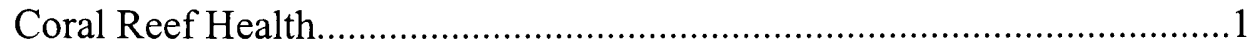

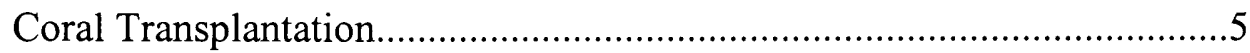

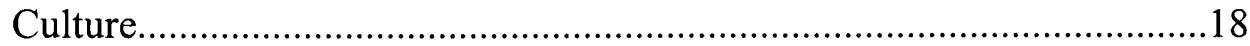

Transplantation for Ship Groundings.....................................................20

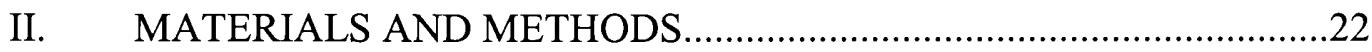

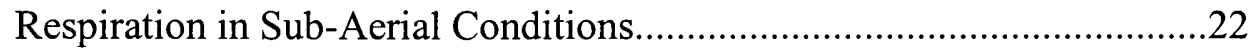

Growth Under Different Feeding Regimes...........................................27

Explantation and Holding $5.1 \mathrm{~cm}$ M. faveolata......................................29

Field vs. Closed Aquarium Storing of $M$. faveolata and A. cervicornis...31

No Maintenance Storage of Acroporids...................................................32

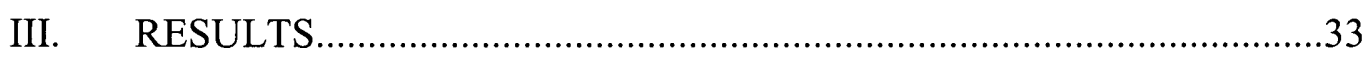

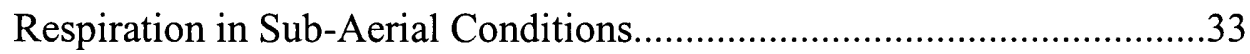

Growth Under Different Feeding Regimes.............................................34

Explantation and Holding 5.1 cm M. faveolata......................................35

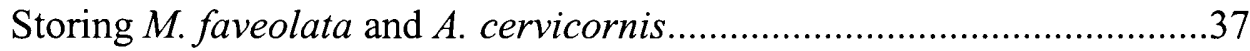

No Maintenance Storage of Acroporids.....................................................40

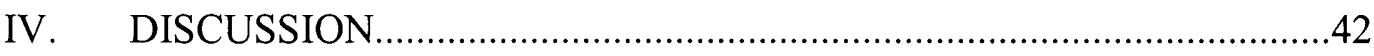

Respiration in Sub-Aerial Conditions....................................................42

Growth Under Different Feeding Regimes..............................................46

Storing M. faveolata and A. cervicornis..............................................50

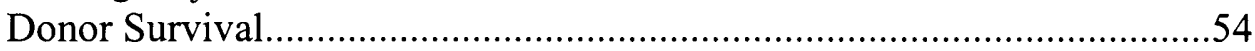

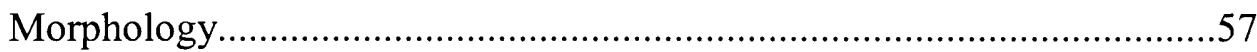

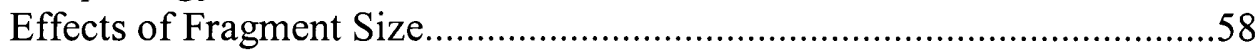

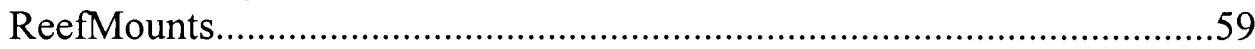

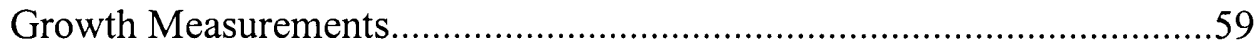

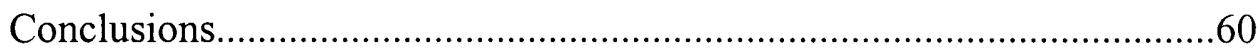

LIST OF REFERENCES.................................................... 77 


\section{LIST OF TABLES}

TABLE

PAGE

1. Respiration Measurements of M. faveolata .........................................................62

2. Buoyant Weights of M. faveolata Over Different Feeding Regimes......................63

3. Polyp Count, Area Change, and Polyp Density Over Different Feeding Regimes..64

4. $\mathrm{CaCO}_{3}$ Accretion in an Aquarium and in the Field.............................................65

5. A. cervicornis and A. palmata Growth Stored In a Tank and In the Field...............66

6. Comparison of M. faveolata Storage Types and Sizes.........................................67 


\section{LIST OF FIGURES}

FIGURE

PAGE

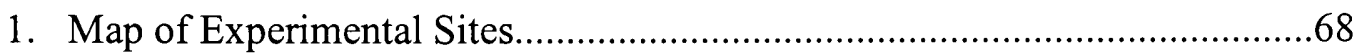

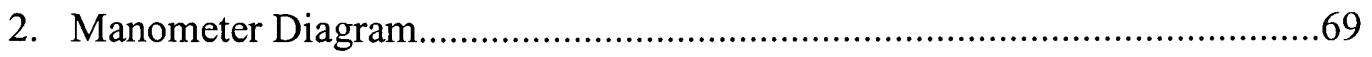

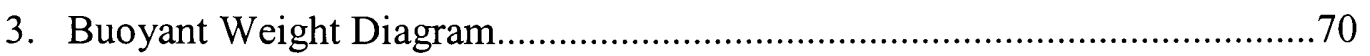

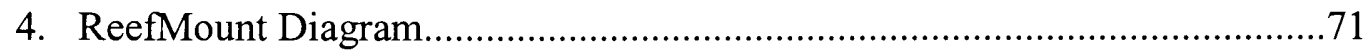

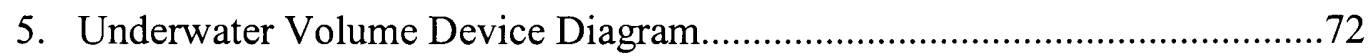

6. Graph of Respiration of M. faveolata in Manometer....................................73

7. Graph Comparing Respiration of M. faveolata at Two Temperatures...........74

8. Graph Comparing Weights of M. faveolata in Different Feeding

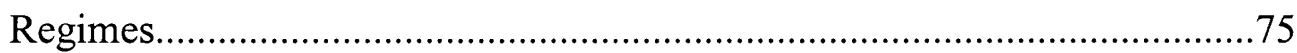

9. Survival of M. faveolata and A. cervicornis Under Three Storage

Methods. . .76 


\section{INTRODUCTION AND LITERATURE REVIEW}

This work reported here explores different aspects of coral transplantation for the purposes of coral reef restoration from physical injury. The "dry method" of transporting coral colonies, the effects of varied feeding regimes on coral colonies in storage, and different methods to store corals to be used for explantation, the use of fragments of a coral colony for transplantation, are examined. Explantation is the extraction of a branch, core, or skirt fragment of a donor colony to start a new colony.

\section{Coral Reef Health}

There is accumulating evidence of a decline in the health of the world's coral reef ecosystems. As early as 1975, Johannes noted Caribbean-wide stress of corals due to sediment loads. Dustan and Halas (1987) showed a decline in abundance, species diversity, and evenness as the result of sedimentation and disease in Carysfort Reef, Key Largo, Florida including shifts in vertical distribution of coral species and/or reduction in mean colony size. Williams and Bunkley-Williams (1990) found an increase in frequency and severity of bleaching events worldwide. This increased frequency gives corals less time to recover between each event with the eventual possibility of no recovery. Porter and Meier (1992) used repeated, multiple photoquadrats along the Florida Keys to show that the corals on the reefs are declining in percent cover and species diversity. Bak and Nieuwland (1993) found a significant decrease in coral cover and colony number between 1973-1983 and 1983-1992 in shallow reefs in Cuaçao and Bonaire, respectively. Species richness decreased in shallow and deep 
reefs for both time periods, as well. Hughes (1994) showed that from 1977 to 1993, coral cover in Jamaica decreased from 52 to $3 \%$ and algal cover increased from 4 to $92 \%$. The zonation of Goreau's (1959) reefs no longer exists.

There are many human activities connected to the decline in coral reef health. These include pollution related to industry and domestic wastes (Bak and Elgershuizen 1976; Elgershuizen and de Kruijf 1976; Thompson and Bright 1977; Galzin 1981; Rodriguez 1981; Szmant-Froelich et al. 1981; Chavez et al. 1985; Dodge and Szmant 1985; Goenaga 1991; Idechong 1999; Idjadi and Edmunds 1999; Le Tissier and Bown 1999); sedimentation (Johannes 1975; Dustan and Halas 1987; Abraham 1999; Edward 1999); sedimentation from dredging (Galzin 1981; Howard and Brown 1984; Goenaga 1991; Edward 1999); disease (Dustan and Halas 1987; Porter and Meier 1992); and thermal pollution (Neudecker 1981; Goenaga 1991). Anchoring, military activities (Rogers et al. 1978), fishing with bleach and explosives (Gil-Navia et al. 1999), and overfishing (Goenaga 1991; McClanahan 1997) are also thought to contribute to the decline of the health of the coral through increased turbidity, siltation, nutrient elevation, and physical destruction. Corals are also harvested for the aquarium industry (Brown 1996; Delbeek and Sprung 1994; Carlson 1987, 1999), building materials (Clark and Edwards 1994) and for betel nut lime (Bowden-Kirby 1999a,b).

There is also the direct impact on corals due to vessels running aground. In 1994, there were 550 reported grounding cases in the Florida Keys National Marine Sanctuary. Because of the cumulative effect of different sources of degradation of coral health, it is important that all efforts be made to restore 
physical damage to coral reefs where the cause has been identified and removed, such as with vessel groundings.

Disease - Disease is any impairment of an organism's vital functions or systems, including interruption, cessation, proliferation, or other malfunction (Santavy and Peters 1997). The first noticed coral diseases, plague, black band and white band, were documented in the 1970's (Antonius 1973, 1977, 1981; Dustin 1977; Gladfelter et al. 1977; Ducklow and Mitchell 1979 a,b). Since these first reports, there has been a steady increase in reports of coral diseases possibly caused by human activities (Bak and Criens 1981; Knowlton et al. 1981; Rogers and Salesky 1981; Gladfelter 1982; Peters et al. 1983; Ramos-Flores 1983; Rutzler and Santavy 1983; van Duyl 1983; Peters 1984, 1993, 1997; Ritchie and Smith 1995; Smith and Ritchie 1995; Richardson 1996, 1997; Carlton and Richardson 1995; Santavy and Peters 1997; Aronson and Precht 1999). These include bleaching (Brown 1987; Szmant and Gassman 1990; Williams and Bunkley-Williams 1990; Peters 1997); white plague (Dustan 1977); white plague type II (Richardson et al. 1998; Richardson et al. 1999); and white pox (Patterson unpub. man.).

Natural Reef Recovery - The time it takes for a reef to recover naturally from damage depends on the location and extent of the damage, recruitment, subsequent perturbations, and what criteria are used to define fully recovered. Small areas of damage of only a few square meters may not even be noticeable within a year. In contrast, large-scale recovery is a long-term process. Coral recruitment in widespread damage areas is slow when there are no fragments or 
colonies for local colonization. Stoddart (1969) predicted that it might take 20-25 years for the reefs most damaged by storms in British Honduras to recover. This estimate was extended to $60-100$ years in a later survey of the same area (Stoddart 1974). Stoddart (1974) eventually concluded that the average recovery period along the British Honduran coast might be 30 years and might be related to the average period of time between major hurricanes. However long it takes for a coral reef to recover from hurricanes or other physical damage, it is years to decades.

Human disturbances are another matter that may extend the recovery time or even jeopardize the recovery of the reefs from the damage (Pearson 1981). Human assistance in recovery, particularly in the cases of known anthropogenic causes such as a ship grounding, is appropriate to mitigate the length of time of recovery.

Defining "recovery" of a coral reef is arbitrary. It is impossible to return a reef to the condition it was before a ship has run aground. A certain amount of damage control and restoration may be necessary to assist the process of recovery. Reefs with low diversity and relief that are seldom visited by tourists may be considered restored with substrate stabilization and the righting and attachment of the larger surviving coral colonies. In contrast, high relief spur and groove formations with high diversity and a large number of visitors (i.e., Looe Key, FL, USA) can not be considered recovered until all evidence of the incident is gone (spurs rebuilt, corals transplanted, and other biota recolonized). However, there seldom is baseline data of the grounding site to use as a guide, though this 
situation is improving (Brown et al. 1999; Bruckner and Bruckner 1999; Call 1999; Castro 1999; Chiappone and Sullivan Sealey 1999; Dokken et al. 1999; Faure et al. 1999; Fisher and Banks 1999; Garzón-Ferreira et al. 1999; Ginsburg et al. 1999; Haskell 1999; Hodgson 1999; Holden and LeDrew 1999; Hourigan 1999; Jaap 1999). The recovery to the level of the surrounding substrate or similar habitat is usually used to guide the process of restoration (Pearson 1981).

\section{Coral Transplantation}

Coral transplants can be used to accelerate the recovery of a reef. By transplanting corals that have reached a size that has a high rate of survival, some substrate complexity can be artificially established and the recovery process of the reef given a head start. Transplanting corals can also immediately provide shelter and substrate for colonization by other biota in the ecosystem. Transplantation of corals has been suggested as a viable, and possibly essential, methodology of expediting the recovery of a damaged or degraded coral reef (Rinkevich 1995; Miller et al. 1993). Transplantation of coral colonies has been widely employed for restoration projects and research (Maragos 1974; Bouchon et al. 1981; Hudson et al. 1989; Clark and Edwards 1994; Clark 1996; Goreau and Hilbertz 1996; Hudson and Goodwin 1996; Jaap et al. 1996; Muñoz-Chagin 1996; van Treeck and Schuhmacher 1997) as well as fragments (Yap and Gomez 1984, 1985; Plucer-Rosario and Randall 1987; Guzman 1991; Yap et al. 1992; Bowden-Kerby 1996; Garcia et al. 1996; Oren and Benayahu 1997; Lindahl 1998). The techniques for removal, transportation and re-attachment are fairly straight forward although varying degrees of success have been reported. Reasons for 
failure may include transport stress, inappropriate species for the restoration site, obtaining donor colonies from an incompatible habitat, poor attachment or subsequent loss in high-energy settings.

Plucer-Rosario and Randall (1987) experimented with transplantation as a method of preserving rare species. Pavona cactus, Leptoseris gardineri, and Montipora pulcherrima were transplanted from areas of stress caused by heated water discharge from power plants and turbidity from real estate development. The colonies were moved to undeveloped areas. The colonies that were transplanted as entire colonies as well as those broken up into shards or nubbins had varied success ranging from 0 to $93.3 \%$ survival. Transplantation may be a viable method of preserving endangered coral species.

Maintaining genetic diversity is essential for the maintenance of stability in ecosystems (Tilman and Downing 1994). However, if limited sources necessitate the use of asexually budded transplants, maintaining genetic diversity may be difficult. Rarity is a concern for the survival of several species (Miller et al. 1993, Plucer-Rosario and Randall 1987). Fucik et al. (1984) and Richmond and Hunter (1990) have moved gravid colonies. Gravid colonies could allow planktonic coral larvae to be introduced into areas in the reefs that were previously inaccessible because of local water movement, currents, tides and/or highly stressed areas (Rinkevich 1995). This strategy would work well with brooding species that release highly developed planulae (Rinkevich and Loya 1979, Johnson 1992) and in coral species with a short planktonic life (reviewed in Harrison and Wallace 1990; Gleason and Brazeau 1999). The planulae of such 
species are likely to have short dispersal distances and will colonize barren areas. This would only be appropriate if the brooding species were found in the restoration site before the grounding or, perhaps, if this were the only source of coral cover available. It would be necessary to bring in colonies from different areas so that the genetic composition in the restoration area would be varied. This could mitigate a complete loss of the introduced corals if disease should become a factor.

Collection of reproductive products may be used for broadcasting species. These can be collected in the field (Rinkevich and Loya 1979) or from spawning corals that have been transplanted to aquaria (Yates and Carlson 1993).

Settlement could then be manipulated to take place onto transferable objects such as dead coral, shells, or artificial material that were made available to the planulae in aquaria. The new colonies can then be transferred to the reef site (Harrison and Wallace 1990). Birthisel et al. (1999) carried out a similar technique in the field using tent-like structures to encourage the planulae to settle onto predetermined piles of live rock stored on the sand.

Culture of fast-growing species, such as the acroporids, under optimal conditions may also be useful in producing coral stocks for restoration. Acropora palmata and A. cervicornis are being considered for the endangered species list. If standing stocks of acroporids can be established, this might be useful in preserving such Caribbean corals that have suffered high mortality over the past two decades due to white band disease, bleaching and predation. Colonies that are still surviving may be more resistant to the conditions causing the mortality since 
they exist in the same conditions that killed their conspecific neighbors. The colonies may eventually be used as donors to reintroduce the species to other reefs from which they have disappeared.

Transporting Corals - Restoration efforts involving transplantation require transportation of the corals, possibly over long distances. Researchers and aquariasts have typically transported corals by the "wet method". This normally consists of keeping the colony in water in a sealed plastic bag, cooler or other container filled with seawater (Davies 1980,1984; Hudson and Diaz 1988, Leletkin et al. 1993). This method is used to avoid exposing the corals to air and possible stress from the exposure. However, wet, unsecured colonies may make them more susceptible to physical damage from movement caused by transport than if the polyps were closed and the colonies padded. Transport has been identified as a source of damage to transplanted coral specimens (Yap and Gomez 1985; Coles and Jokiel 1977).

Some researchers have been using variations on the dry method to transport the corals where corals are kept moist in plastic bags (D. Allemand pers. com. to E. Mueller) and reported success for up to 72 hours. Carlson $(1987,1999)$ wraps corals in wet strips of plastic for transport periods of up to 24 hours. Becker and Mueller (in press) placed coral colonies into plastic bags with approximately $10-30 \mathrm{ml}$ of seawater (depending on the size of the colony) while placing them in a cooler padded with bubble wrap and/or newspaper. One or two ice blocks are added as needed to keep the temperature low while in transit by boat or car. These corals have been out of the water 1-3 hours at a time. Becker and Mueller (in 
press) transported Montastraea faveolata, Acropora cervicornis, and A. palmata with no apparent ill effects in movement from the field to aquaria in the lab and vice versa. When placed into the aquaria, the polyps remain retracted, but they open and function within two hours and will feed on Artemia if offered. There is no visible tissue loss.

The dry transport method works but no one has investigated how and why it does. This study is the first to examine respiration while under transport conditions.

Keeping and Feeding Corals - There are several reasons besides aesthetics for keeping corals in aquaria. One is to culture corals for experimentation. This allows control of conditions under which corals are kept and allow multiple corals of the same genetic makeup to be asexually produced for controlled experiments. Another reason would be raising corals for the aquarium trade, which could mitigate the taking of "wild" corals from the reef system for home aquaria. Corals could also be rescued from a reef damaged by a vessel impact so that they may be used in the reef's eventual restoration.

Closed systems offer the potential to provide corals with optimum growth conditions. Although optimum light and temperatures are fairly well established for reef corals, optimization of feeding regimes is not well established. Corals have the ability to feed at two trophic levels (Johannes 1974; Trench 1979). They feed autotrophically from translocated photosynthetic products produced by endosymbiotic xoozanthellae (Muscatine and Hand 1958; Lewis and Smith 1971). Corals have been known to live with little or no feeding because of the 
photosynthetic products (Muscatine et al. 1983; Achituv and Dubinski 1990; Sebens 1997a). Kawaguti (1965) did not feed Oulastrea cripata for 15 months and they grew and three other species of corals in his care did the same for 3 months. Corals also feed themselves heterotrophically through prey capture of zooplankton in the water column, suspension feeding, ciliary-mucoid feeding and absorption of dissolved organic matter (Muscatine 1973). Yonge and Nicholls (1931) showed that fed corals grew and starved corals shrank in live tissue area. Porter (1974) found an insufficient amount of zooplankton in the water column to feed corals while Coles (1969) found that some corals in lab studies were capable of capturing enough plankton to satisfy their respiration requirements three to four times over.

The nutritional needs and contribution of zooxanthellae are thought to vary from species to species (Johannes et al. 1970; Porter 1976). Porter (1974) estimated that 0.2 to $10 \%$ of the energy required by Montastraea cavernosa was from zooplankton and the rest from zooxanthellae. Johannes and Tepley (1974) calculated that $90 \%$ of the respiration energy of Porites lobata was from zooxanthellae. Franzisket (1970) found that large-polyped corals were better at catching zooplankton and had lower rates of metabolism than their small-polyped counterparts and so were less dependent on their zooxanthellae for carbon. The small-polyped corals, because of their poorer prey capture abilities, probably are more dependent on their symbionts for carbon. Corals are usually nitrogen limited or carbon limited in low light or flow (Sebens 1997b). Zooxanthellae recycle nitrogenous wastes and remove inorganic nitrogen from the surrounding seawater 
(Muscatine 1973; Sebens 1997). However, this is thought not to be enough to sustain coral growth (Sebens 1987). Any need for nitrogen, phosphorus or other nutrient not supplied by the zooxanthellae may be supplied from zooplankton capture (Muscatine review 1973; Sebens 1987; Johnson and Sebens 1993).

Nutrients may also be obtained with the ingestion of dead or "moribund" animal matter (Yonge 1968).

This study examined growth of Montastraea faveolata under different feeding regimes using $M$. faveolata, a major reef building coral of the Caribbean that is often utilized in restoration projects. An optimal feeding regime would increase growth rates thus minimizing grow out time in aquaria.

Transplanting Corals - When conducting reef restoration, care must be taken to minimize the impact of removing corals from the donor site. Simply transplanting whole colonies from one site to another impacts the donor site. By generating several small colonies from a larger colony while leaving the majority of the donor coral intact, the complexity of the donor site can be preserved. Careful fragmentation or explantation can do this. Disease and agents of bioerosion can be excluded from entering the skeleton of the donor colonies by protecting the wounds caused by the fragmentation with epoxy or clay. Harvesting fragments as small as possible, while maintaining a high rate of survival when explanted, can also minimize damage (Gleason 1999). Minimal size may also make it possible to explant more starter colonies to the grounding site. Bouchon et al. (1981) transported 42 colonies belonging to 21 genera onto an artificial reef in an area devoid of coral reefs. One year later, $64 \%$ of the 
transplanted colonies survived and 16 newly settled colonies belonging to six genera were present.

Different methods of attachment of coral transplants to substrate have been tried. Yap and Gomez $(1984,1985)$ experimented with tires and concrete flagstones as coral attachment bases rather than attaching the corals directly to the reef. They found no significant difference in growth rates for the transplants as compared to the controls that were shammed. Harriott and Fisk (1988) documented total mortality of hard corals after a cyclone that occurred 9 months after transplantation in Australia. Clark and Edwards (1994) examined coral transplants in studies on three different artificial reef formations. They reported $76.6 \%, 62.0 \%$, and $67.0 \%$ survival rates. Goreau and Hilbertz (1996) successfully transplanted coral fragments onto artificial reefs that were created through precipitation of limestone and magnesium by seawater electrolysis. MuñozChagin (1996) carried out an ambitious transplantation experiment. A pier was to be built on Cozumel Island, Mexico. From April to October 1995, 23,000 sessile animals, including 2,400 corals and 600 sponges, were moved from the construction site of the pier to 34 artificial marine habitats in the form of small artificial reefs. Even after Hurricane Roxanne, the mortality was less than 3\% for these transplants. Dodge et al. (1999) removed and reattached corals that were on an outfall pipe that needed maintenance after Hurricane Andrew.

Other studies have examined methods of affixing transplants. Several researchers favor use of epoxies for attaching corals to the substrate or to artificial bases (Plucer-Rosario and Randall 1987; Garcia et al. 1996; Jaap et al. 1996; Yap 
and Gomez 1984,1985; Yap et al. 1992). In this manner coral nubbins have been attached successfully to terracotta bricks (Plucer-Rosario and Randall 1987) and tires (Yap and Gomez 1984, 1985; Yap et al. 1992). Garcia et al. (1996) found by direct comparison that epoxy provided a more stable attachment method than tying fragments of Acropora palmata with cord to dead coral or poles. Jaap et al. (1996) drilled holes into the substrate and the bottom of the colony then inserted stainless steel pins into corresponding holes to increase the stability of the cementation.

In some cases, coral pieces were simply scattered on the sea floor. PlucerRosario and Randall (1987) found that coral nubbins placed without attachment on the sea floor had a much lower survival rate than attaching the nubbins to bricks. Bowden-Kerby $(1996,1999)$ found that survival of corals transplanted onto sand was size-dependent. All pieces of Acropora cervicornis 8-12 cm died $(n=160)$ while $95 \%$ of those $>30 \mathrm{~cm}$ survived $(n=60)$. The survival rate was high for all sizes of $A$. cervicornis transplanted onto rubble-covered reef flats, even those $<5 \mathrm{~cm}$ in length. The presence of solid substrate was an advantage to the coral's survival. He had better success with relatively larger branches of $A$. cervicornis and A. prolifera placed on reef flat rubble and back reefs (BowdenKerby 1999a,b). Plucer-Rosario and Randall (1987), using a similar technique, simply placed full-grown coral colonies on the bottom. This was successful but they recommended attaching the colonies to the substrate in future studies for ease of identification and location, especially since dead colonies blended into the surrounding environment. 
Cements of different types and configurations have also been used. Clark (1996) placed the bases of coral colonies into bags of cement and simply set them out to simulate a stable attachment. Hudson et al. (1989) made concrete domes to which 11 species of hard coral and 10 species of soft coral were cemented using a mixture of silica sand, Chattahoochee gravel and Portland Type II cement. Hudson and Goodwin (1996) righted toppled Dendrogyra cylindrus (pillar coral) by embedding their bases in cement-filled boreholes drilled into the reef. Graham and Fitzgerald (1999) devised an attachment method using expansion anchors and threaded rods. In addition to anchoring to the substrate, this method allows the infauna to continue to inhabit the underside of the coral without killing them as might happen with epoxy or cement.

Mortality of coral transplants from stingrays in Pohnpei sand flats made it necessary for Bowden-Kerby (1996) to attach transplants to wire frames. Iliff et al. (1999) tied A. palmata to the reef with some success (except for invasion by the sponge Cliona $s p$ ).

Firm attachment was not always the goal for of the method used. Clark (1996) screwed hooks into the bases of colonies and attached the corals to the substrate with ropes through the hooks to simulate a loose attachment in the wild.

Injury - Transplantation may cause injury to coral tissue. Corals have a limited energy budget and tissue regeneration is an energy-demanding process (Meesters 1992). Tissue damage is normally repaired in two steps: 1) undifferentiated tissue covers over the wound, and 2) polyps, pigment, and skeletal structures are subsequently formed. If the coral has to expend energy for 
attachment, lesions may heal more slowly. Slower rates of tissue regeneration leave the coral open to potential invasion by bacteria, algae, and boring organisms, potentially decreasing the chances for long-term survival. However, once recovery has been completed the coral's chances of survival, growth, and reproduction come within the range of similarly injured nontransplants (Clark 1996). Since smaller wounds have a more successful healing rate than larger wounds (Meesters et al. 1994; Meesters et al. 1997; Meesters et al. 1997; Croquer et al. 1999), smaller transplants would be more desirable for the health and recovery of the donor colony.

The recovery of coral transplants is affected by environmental conditions, and these must be considered when moving colonies or creating transplants. Recovery from injury depends on species, degree of sedimentation, extent of bleaching, and extent of tissue damage (Bak and Criens 1981, Bak 1983, Meesters et al. 1992). The redirection of energy toward healing can affect growth and reproduction as well as the ability to fight adverse conditions in the environment such as fluctuations in temperature. For example, during a bleaching event in the Philippines Acropora hyacinthus and Pocillopora damicornis transplants bleached much more extensively than the controls that were not transplanted; likewise, mortality was much higher in transplants than in controls (Yap et al 1992). Clark (1996) found that transplant success also depends on environmental conditions at the recipient site (as well as coral species). When corals were deliberately injured and transplanted from a sheltered to a higher energy wave environment, damage repair was slowest at the most exposed locations. Even the 
colonies that recovered began to exhibit tissue degeneration later, perhaps due to the combined effect of wave action and suspended particles on the coral (Clark 1996). The energy expense of continuous tissue repair could have been too much for the corals. Clark (1996) also found that tissue repair capacity differs among species. Porites lobata appeared to initially repair lesions of the same size and depth more slowly than Favia speciosa and Goniastrea aspera.

Injuries also occur during transportation as the coral comes into contact with other corals or with the transport container (Clark, 1996). Yap and Gomez (1985) concluded that when transplants were compared with controls the only discernible cause of increased mortality lay in the breakage, handling, and attachment of the transplanted colonies.

Yap et al. (1992) found that Pocillopora damicornis transplants had a high mortality rate during the first year from injury inflicted during the transplant process, but, the remaining corals survived well the following year. PlucerRosario and Randall (1987) found that whole transplanted colonies survived better than shards and nubbins that were broken from a larger coral colony. Whole colonies of Pavona cactus survived at the rate of $26.6 \%$ in contrast to $6.0 \%$ of shards. Whole Montipora pulcherrima survived at the rate of $10.0 \%$ in contrast to $0.0 \%$ of shards.

Yap and Gomez (1985) found that the health of transplanted colonies was affected by the time of year of the transplant. In the Philippines, transplantation during the cool months and well before the onset of the warm months was more successful than for those transplanted during the warm months. 
Yap and Gomez (1985) also found that growth rates of transplants appear to have been suppressed where the amount of resuspended sediment was greater. Removal of sediment from the coral surface has an energy cost (Dodge et al. 1974). The presence of sediment itself decreases the amount of light (Rogers 1979), and interferes with the acquisition of planktonic food (Bak 1978). Yap and Gomez (1984) also found that transplant and nontransplant growth was positively correlated with temperature (but not significantly correlated with day length). The health of the transplants was not affected by the proximity to the parent colony.

Hudson (1981) demonstrated that temperature, among other factors, was a consideration when choosing sites for transplantation. He found that Montastraea annularis experienced full mortality when transplanted to near-shore waters where temperature was $<14^{\circ} \mathrm{C}$ due to runoff from land.

Other Factors - It is important to choose which species to transplant carefully. Clark and Edwards (1994) found Favia sp., Favites sp., and Porites sp. to be difficult to work with. They state that they would not have chosen these species if they had been more selective in choosing which species to use. It was never mentioned why these species were difficult to work with.

Yap et al. (1992) discuss how possible differences in life cycle strategies of transplanted corals may influence how well a coral can be expected to survive. They hypothesize that the life cycle of $A$. hyacinthus shows a tendency toward a high r-mode strategy with rapid growth but high mortality. This strategy may make this species less appropriate for transplantation. Since $A$. hyacinthus had been observed releasing gametes into the water, its reproductive strategy may rely 
more on gametes than budding, consequently, colony transplantation may not be necessary (Yap et al. 1992). P. frondifera had the highest growth rates and no mortality. This coral exhibited the best response to transplantation. Finally, $P$. damicornis has an intermediate growth strategy and a relatively high mortality. The transplants fared poorly in the initial part of the experiment though they appeared to recover after a year.

Orientation of the transplanted coral may be a factor to consider for the coral's survival when attached to a surface. Branches of Acropora pulcha were laid flat onto tires by Yap and Gomez $(1984,1985)$. The light exposure that particular branches had been subjected to was altered from that of the parent colony. The new growth grew upward and not toward in the same orientation as the parent branch. The change in light exposure may be the difference between success and failure of the transplants to acclimate and survive.

\section{Culture}

Since we know that corals can be transplanted, the next question is whether or not corals can be cultivated by some "farming" technique so that colonies can be transplanted with a minimum amount of destruction to a donor site. Rinkevich (1995) sees coral farming, both in aquaria and in sheltered coves, as a method to create a stock of corals to be transplanted to the wild. This would be very useful in the in the Florida Keys, where there are relatively few potential donor populations of large adult colonies available for transplanting to grounding sites. Multiple explants could be obtained from the farmed corals through fragmentation. 
Cultured corals can be used for experimentation as well as transplantation to restoration sites (Jaubert 1989, 1991; Adey 1983; Jaubert et al. 1996). The European Ocanographic Centre at Monoco (Jaubert et al. 1996) has been very successful in growing many species of Indo-Pacific corals.

Atkinson et al. (1995) reported that the Waikiki Aquarium has maintained cultures of living corals in semi-closed systems since 1980 . The collection presently includes 57 species of scleractinian corals raised in an outdoor, opensystem "coral farm". The aquarium distributed 269 fragments to public aquariums and researchers in the U. S. in 1996 (Carlson 1996, 1999). Borneman and Lowrie (1999) tell of over 150 species of scleractinians cultivated successfully. If this success could be accomplished with most species, corals could be grown in rearing facilities, and then transplanted to denuded reefs, ship grounding sites, or to artificial reefs, requiring but a limited number of corals or coral pieces from natural reefs.

Based on the observation that corals are spawning in the Waikiki Aquarium tanks, raising corals from the planula larvae instead of fragments may be possible (Carlson 1996). This could be especially important for corals that use sexual reproduction instead of fragmentation as their primary form of reproduction. The use of larvae might require more time to grow transplantable colonies but this method may be less traumatic for the corals that may be shipped great distances. The new colonies could be attached to a permanent, movable base making it unnecessary to stress the colonies with detachment and attachment procedures. 


\section{Transplantation for Ship Groundings}

Over the past 15 years, there have been a number of large vessel groundings on coral reefs in the Florida Keys including the M/V Wellwood (1984), M/V Elpis (1989), the M/V Maitland (1989), R/V Columbus Iselin (1994), and the Contship Houston (1997). The sizes of the damaged areas range from hundreds to thousands of square meters. Natural re-establishment of scleractinian corals has been slow in these areas, apparently because of poor sexual recruitment and/or post-settlement survival. Aronson and Swanson (1997) showed that after 10 years the $M / V$ Wellwood grounding site that was not structurally restored was biologically and statistically more similar to a hardground than to its original spur and groove formations. Cores taken from spurs on reefs of the Florida Keys indicate that these structures typically represent as much as 4,000-6,500 years of coral growth (Shinn et al. 1981).

Because of the extremely long natural recovery times and the potential for further damage to surrounding areas due to an unstable substrate and rolling detached coral colonies, several large grounding site repair projects have been undertaken in all of the above-named vessel sites. Priority has generally been placed on site stabilization by re-securing large coral colonies, removing loose rubble or covering it with concrete matting, and structural restoration to prevent further erosion (Curtis 1985; Hudson and Diaz 1988). Hard substrates in the Keys are typically a veneer of cemented limestone overlying unconsolidated reefal material. Thus, damage to the limestone veneer allows erosion of adjacent areas, consequently enlarging the original damage area. Recently, Hurricane Georges 
was estimated to have doubled the size of the R/V Columbus Iselin grounding site at Looe Key prior to structural restoration (NOAA 1999; R. Spadoni and C. Kruempel, pers. com.).

Site restoration goals have not been defined on a uniform basis. At locations where tourist visitation is low, stabilization of large coral colonies and the substrate has been considered sufficient. In the case of the R/V Columbus Iselin restoration, the site is a spur-and-groove formation with high visitor use. Here, reconstruction/stabilization and aesthetic appeal are the principal concerns. Some attempts have been made to address restoration of reef function, largely through transplantation of corals and other major benthic fauna. The surrounding substrate or similar habitat must be used as a guide for restoration because the nature of the pre-impact community composition is seldom available (Pearson 1981).

To minimize damage to donor colonies, I examined the effect of size on viability of M. faveolata explants (annularis complex; Knowlton et al. 1992), one of the major reef-building corals in the Caribbean. The advantages and disadvantages of closed aquaria, open systems and other means of holding and culturing coral explants were explored. In cases where reef damage requires timeconsuming assessment, engineering and structural restoration, such approaches could be useful for maintaining the viability of coral fragments generated during the damage. 


\section{MATERIALS AND METHODS}

\section{Respiration in Sub-Aerial Conditions}

Coral Collection and Preparation - As colonies were selected for these experiments, they were assigned a letter name $(\mathrm{A}, \mathrm{B}, \mathrm{C} \ldots)$ and their explants assigned the corresponding letter and number (A1, A2, A3 ...). Three colonies of Montastraea faveolata were haphazardly selected from an offshore patch reef just east of the Looe Key Special Use Area in the Florida Keys National Marine Sanctuary, on February 3, 1999 (Figure 1) and designated K, L, and M. These colonies appeared to be healthy and were over a meter tall with ample area available for explantation. Fragments were broken off from the skirts (the bottom section of the colony that flares out from the substrate) with hammer and chisel.

The fragments were transported back to Pigeon Key Marine Research Center by the dry method (Carlson 1987, 1999; Becker and Mueller, in press). Corals were collected and placed into plastic bags. Once on the surface, all but a small amount of water $(20-50 \mathrm{ml})$ was poured out of the bags. The openings of the bags were folded over and the coral placed in a cooler with either wadded newspaper or bubble wrap for padding. One or two pieces of reusable ice blocks were placed on top to prevent overheating. Several pieces were too large for the plastic bags available and were wrapped in wet bubble wrap.

The skirt fragments from each colony were placed in separate closed aquaria (567.75 liters each) set up following the Jaubert $(1989,1991)$ Microcean ${ }^{\mathrm{TM}}$ system. Lighting was provided by 1000 watt metal halide lamps (5500K) at $\sim 350 \mu \mathrm{mol}$ photons $\mathrm{m}^{-2} \mathrm{~s}^{-1}$ near the bottom on a $12 \mathrm{hr}$ light $/ 12 \mathrm{hr}$ dark 
cycle. Temperature was set at $27^{\circ} \mathrm{C}$ but varied from 25 to $30^{\circ} \mathrm{C}$ due to an unreliable electrical source.

The day after transport, fragments from each colony were cut into twelve $5 \times 5 \mathrm{~cm}$ pieces with a wet brick saw using seawater for lubricant. The pieces were trimmed of encrusting and boring organisms from the underside of each piece. Two days later the bare skeleton on the sides and bottoms of the squares were patted dry and coated with epoxy. The epoxy prevented encrusting organisms from attaching to the skeleton, which are difficult, if not impossible, to clean. Identifying marks were carved into the epoxy and the corals were placed on underwater paper in a pan of seawater until it hardened. The marked samples were then returned to the aquaria. Applying the epoxy took two days to accomplish. The corals were then prepared for a feeding experiment (see below) which began a week later and ran for 10 weeks. Sixteen weeks later the respiration measurements reported in this thesis were performed on 24 of the same corals. The corals were fed Artemia nauplii (brine shrimp) once a week for the intervening weeks and during this experiment.

Manometer Construction - Two incubation chambers were constructed from glass jars with hard plastic lids. Two holes were drilled into the lids to fit a thermometer and a $1 \mathrm{ml}$-glass pipette, marked in $0.025 \mathrm{ml}$ segments. Short sections of aquarium tubing lubricated with vacuum grease were used as gaskets and sealant, respectively, around the thermometer, pipette and under the jar lids. The jars and lids were masked with aluminum tape to block out light, preventing photosynthesis by the zooxanthellae. Flexible opaque sheets of plastic were taped 
around the thermometers and pipettes next to the chamber to prevent light from entering through the pipette or thermometer. After construction, the chambers were tested for air-tightness by submerging the chamber except for the open end of the pipette in water and gently blowing into the pipette and watching for bubbles. A one-pound lead dive weight was placed in the jar to keep it from floating and a 2-3-pound weight was placed on either side of the jars for stabilization in the water bath (Figure 2).

Experimental Procedure - Encrusting organisms were scraped while submerging samples into a pan of seawater. Two of the $\sim 5 \mathrm{~cm}^{2}$ coral samples from the same colony were used in each experimental replication to increase surface area. Some of the corals had grown over the sides of the epoxy making them difficult to handle without damaging the tissue. When a choice was necessary, the cleaning was not as thorough to avoid damaging the coral tissue. Each coral was placed in a seawater-rinsed plastic bag with approximately $10-20$ $\mathrm{ml}$ seawater remaining to keep the coral moist. The opening of the bag was loosely folded over the top so that the water would not run out but so that air could be exchanged. The corals were placed into the chambers along with a plastic vial with holes drilled in it filled with soda lime to absorb $\mathrm{CO}_{2}$. A temperature logger (Onset Optic StowAway) was also placed into the chamber to record the temperature every minute. After wetting the inside of the pipette with distilled water, to facilitate the movement of the soap bubble, the lid was screwed on without the thermometer inserted. An outward movement of the water in the pipette upon insertion of the thermometer was confirmation of the airtight seal. As 
a further confirmation of a good seal, the pipette was gently blown into to check for leaks. The chamber was carefully placed into the water bath.

Temperature and air pressure were allowed to equalize for one hour after which a bubble of soapy water was placed into the end of the pipette. The pipette was then observed and the distance and time of the movements of the bubble were recorded. To mitigate the effect of surface tension on the initiation of movement of the soap bubble, the end of a section of flexible aquarium tubing was placed over the end of the pipette while the other end was gently blown into. This pushed the bubble past the point where the surface tension may have been preventing the bubble from moving. This method was also used to periodically "redampen" the pipette to keep dry spots within the pipette from hindering the movement of the soap bubble. When the bubble moved toward the chamber, indicating the soda lime was adsorbing $\mathrm{CO}_{2}$, the start time was noted so that the temperature recorded by the logger could be used in volume calculations. Since respiration was not constant and did not occur at regular intervals, the apparatus had to be watched constantly. At times, the beginning of the movement was missed. In this case, the remaining distance traveled was timed with a stopwatch and measured. The distance that the bubble traveled before timing began was included in the total volume $\mathrm{O}_{2}$ consumed, but not in the rate calculations.

A control chamber without corals was also placed in the water bath to observe the influences of temperature and barometric pressure on the volume of air. If the bubble in the control chamber showed movement when the 
experimental chambers moved, the measurement was deemed suspect and not used.

For each experiment, the corals were kept in the chamber for a total of eight hours. After this period, the corals were returned to the aquarium and observed. There were two runs for each pair of corals, one at $27^{\circ} \mathrm{C}$ then at $25^{\circ} \mathrm{C}$. All of the $27^{\circ} \mathrm{C}$ experiments were completed before attempting those at lower temperatures. This gave the corals at least 12 days to stabilize from any effects of the first run.

Photographs were taken with a digital camera (Kodak DC 260 Zoom) of the top and all four sides of each coral were taken within 4 days of its run in the chamber. These images were analyzed using Paint (Microsoft), Photoshop (Adobe) and Scion Image (NIH) for polyp count and area measurement of each coral's tissue.

Calculations - The rate of respiration was calculated by the following formula:

$$
\left(\frac{(v o l * 60)}{t} * \frac{(b p)}{760} * \frac{(273)}{T+273}\right) / A
$$

[equation 1]

where vol is the measured and timed volume of $\mathrm{O}_{2}$ consumed $(\mu \mathrm{l})$, bp is barometric pressure (mm $\mathrm{Hg}), \mathrm{t}$ is time $(\mathrm{sec}), \mathrm{T}$ is temperature $\left({ }^{\circ} \mathrm{C}\right)$, and $\mathrm{A}$ is total area $\left(\mathrm{cm}^{2}\right)$ of coral tissue. The barometric pressure was the average of the encompassing hourly measurements of each measurement of pressure made by the National Oceanographic and Atmospheric Administration C-MAN station at 
Sombrero Reef approximately $4 \mathrm{~km}$ away. The temperature for the calculation was the weighted average temperature recorded over the time of the respiration event. The area was determined from the digital images. Respiration rates, time of respiration and volume of oxygen consumed were compared. The volume of $\mathrm{O}_{2}$ consumed was calculated by:

$$
\left((v o l) * \frac{(b p)}{760} * \frac{(273)}{T+273}\right) / A
$$

[equation 2]

adapted from equation 1 . The time in the chamber after the one hour equilibration time was divided into two $3.5 \mathrm{~h}$ segments and compared. All comparisons were made by ANOVA and LSD test (STATISTICA).

\section{Growth Under Different Feeding Regimes}

This experiment was performed prior to the respiration experiment using the same $5 \times 5 \mathrm{~cm}^{2} M$. faveolata squares. The day after the corals were cut into squares, they were weighed by the buoyant weight method (Davies 1989, Dodge et al. 1984) with the assumption that the density of aragonite is 2.93 (Jokiel et al. 1978). After epoxy was applied to the sides and bottoms (see above) the squares were then weighed again and the weight of the epoxy was determined by subtraction. The weight of the epoxy was eliminated from the calculations of air weight.

Buoyant weight was measured using a balance placed (Mettler) on top of a acrylic support placed on top of a 18.9 liter aquarium. The sides of the support reduced air movement over the aquarium. A wire was hung from the scale into the 
water in the aquarium holding a acrylic platform on which the corals were placed (Figure 3). After taring the balance, the coral was slowly placed onto the platform in such a way as to not disturb the water any more than necessary. The water was given 2 minutes to become still then a reading was taken. The following calculation was used to compute the weight of the coral in air:

$$
\left.\frac{W w}{1-(D w / D a}\right)
$$

[equation 3]

where $\mathrm{Ww}$ is the weight of the coral in the water, Dw is the density of the water in the aquarium and $\mathrm{Da}$ is the density of aragonite.

After a weeklong recovery period, the corals were randomly assigned to one of three aquaria so that four squares from each colony were in each aquarium. The corals were weighed again and pictures were taken of the live surface with a digital camera for analysis of surface area and polyp count.

The aquaria were randomly assigned to a feeding schedule of once, twice, or three times per week (Friday; Monday, Friday; Monday, Wednesday, Friday). Brine shrimp were removed from the aquarium by ingestion by the corals or other animals in the aquarium filtration system. Digestion takes $3-13$ hours (Yonge and Nichols 1931; Porter 1978) so the corals should have been ready to feed each time. Since M. faveolata feeds mostly at night in the field, the corals were fed in the evening between 1900 and 2300 after dusk. 
To ensure that the volume of each feeding was consistent, the brine shrimp were drained in a net for at least 11 minutes before $2 \mathrm{ml}$ (dry weight of $0.75 \mathrm{~g} \pm$ 0.05) was scooped out for each feeding. When the Artemia were placed into the aquaria, the pumps for the filter and the power heads for oscillation were turned off for 30 minutes so that the water was still; this had been the method of feeding the corals in the past in this facility. However, due to findings of increased prey capture with water flow (Helmuth and Sebens 1993; Johnson and Sebens 1993), the power heads were turned back on after 30 minutes, with the pumps to the filters off, allowing oscillation in the aquaria but no filtration. This way the corals had the opportunity to feed under both conditions.

The experiment ran for 70 days. Buoyant weights were measured at 28 , 42, 56 and 70 days. Photographs were again taken with a digital camera of the top and the four sides on the $70^{\text {th }}$ day. The images were analyzed as described earlier. Statistical comparisons were made of percent increase in polyp count, increased area and change in polyp density. These comparisons were made by using ANOVA and LSD post hoc test, where appropriate.

\section{Explantation and Holding $5.1 \mathrm{~cm}$ M. faveolata}

On 29 May 1996, three donor colonies of M. faveolata were haphazardly selected for apparent good health and being large enough for the explantation at an offshore patch reef within the Looe Key National Marine Sanctuary (Figure 1). This area is now in the Looe Key Special Use Zone of the Florida Keys National Marine Sanctuary. Twelve $5.1 \mathrm{~cm}$ in diameter cores were extracted from the sides of each of the donor colonies using a pneumatic drill fitted with a diamond core 
bit. The cores were transported back to the Pigeon Key Marine Research Center (PKMRC) in seawater-filled coolers. The holes in the donor colonies were later filled with a mixture of epoxy and fine carbonate sand to prevent attack by pathogenic microorganisms and bioeroders and to facilitate aesthetic recovery of the colonies.

The cores were attached to ReefMounts (mushroom-shaped, fired ceramic pedestals designed by E. Mueller; Figure 4) with epoxy (Devcon). The mounted explants were then placed in an aquarium. The buoyant weight of each core and mount were measured at that time and periodically thereafter. Before each weighing, all organisms and their calcareous material were carefully removed from the explants and their ReefMounts.

In May 1997, one year later, the explants were cleaned and weighed prior to placing them in the field. Since the entire skeleton was not covered on each core, epoxy was applied to any exposed skeleton and then each was reweighed. Two mostly dead Montastraea mounds, designated a and b, on the Looe Key forereef were selected as Restoration Test Sites (RTS1 a \& b; Figure 1). Each of the explants was randomly assigned to one of the mounds, equally distributed to one of three orientations: horizontal, vertical, and intermediate (18 cores on each mound with 6 at each orientation). Holes were drilled in areas with no live coral ( $2.54 \mathrm{~cm}$ diameter $\times 7.6 \mathrm{~cm}$ deep) to accommodate the stems of the ReefMounts and their explants. Epoxy was applied sparingly so that the explants could be removed for re-weighing. 
The corals were retrieved in May of 1998 and 1999, transported back to PKMRC, cleaned of encrusting organisms and reweighed. A nested MANOVA was performed, testing for treatment, mound, and orientation effects. A separate ANOVA was performed to compare colony and treatment effects.

\section{Field vs. Closed Aquarium Storing of $M$. faveolata and $A$. cervicornis}

Growth and survival of $A$. cervicornis and $M$. faveolata in the Florida Keys were compared using three treatments. In August 1997, twelve $2.5 \mathrm{~cm}$ cores of M. faveolata were extracted from each of three colonies that were selected haphazardly from an offshore patch reef near the Looe Key Special Use Area. The corals were attached to ReefMounts and the volumes of the cores measured (see below). Four explants from each donor colony were left in aquaria and the remaining eight were taken back into the field. Four explants from each colony were placed onto an array (5.5 m deep) within the Looe Key Special Use Zone (RTS2). The remaining four explants from each colony were placed on a grounding site at an inshore patch reef (RTS3; Newfound Harbor Sanctuary Preservation Area) where holes for the ReefMounts had been drilled. ReefMounts were placed in holes (all vertical) without any epoxy for easy retrieval. The condition and volumes of the explants were periodically measured through May 1999.

In the field, the volumes were measured by placing the explant on a raised level platform with an inverted funnel coming through the platform. A graduated cup was placed over the coral that was then filled through the funnel with air from 
a regulator (Figure 5). Once filled, the cup was carefully lifted off of the coral, the coral removed, and the cup replaced onto the platform. The amount of water in the cup was equal to the combined volumes of the coral and the epoxy. The corals were then reattached to the array or placed back on the reef substrate.

In November 1997, a similar protocol was employed with $A$. cervicornis. Bone cutters were used to collect twelve branches (approximately $7 \mathrm{~cm}$ long) from each of three colonies from the same reef area as the $M$. faveolata cores. The thirty-six branches were attached in an upright position to Key Largo limestone blocks (approximately $4 \times 12 \times 2 \mathrm{~cm}$ ) with epoxy. The branches were randomly assigned to one of three treatments: storage on the array at RTS2, in an aquarium, or placed directly onto reef substrate without epoxy near RTS2. The volumes and lengths of the aquarium-stored explants were measured in the laboratory. Measurements were made in situ for field-based explants. Due to breakage, loss and high variability in the measurements of growth rates a statistical analysis was not performed for either species.

Survival was analyzed using the Kruskall-Wallis test (Statistica).

\section{No Maintenance Storage of Acroporids}

This experiment examined the growth of acroporids in an open seawater system and in the field with no maintenance. In July 1997, two donor colonies of Acropora cervicornis and two colonies of $A$. palmata were haphazardly selected near Lee Stocking Island, Exumas, Bahamas. Twelve branches, each approximately $7 \mathrm{~cm}$ long, were collected from each colony with the use of bone cutters. The branches were mounted with epoxy in an upright position onto PVC 
plates. The buoyant weights of the branches were measured before and after attachment. Photographs were made of each explant using a Nikonos camera with an extension tube. The branches were randomly assigned to one of two treatments as follows. Six of the branches from each species were placed on a PVC frame in $\mathrm{a} \sim 1.5 \mathrm{~m}$ deep tank, part of an open seawater system. A mesh screen over part of the tank protected the samples from the afternoon sun. The remaining branches were placed on a stainless steel array on a patch reef near Bock Cay at a depth of $\sim 3 \mathrm{~m}$. This array was a single pole inserted into a pipe hammered into the substrate. A cross bar attached to the upper end of the pole formed two arms. Each arm had three additional cross pieces creating six smaller arms that held the PVC plates. After 10 months all corals were collected, photographed, cleaned of encrusting organisms and reweighed. The corals were then removed from their PVC mounts, returned to near the location of their donor colony and attached to the substrate using epoxy.

The vertical linear extension (measured from the base to the tallest point of the coral) and maximum basal width (maximum diameter of the base) were determined from photographs. Data were examined using ANOVA (Statistica). One dead and two broken A. cervicornis branches were excluded from the linear extension and $\mathrm{CaCO}_{2}$ accretion analysis. The two broken branches were included in the basal growth analysis. 


\section{RESULTS}

\section{Respiration in Sub-Aerial Conditions}

All the corals survived the experimental procedure at both temperatures and showed no ill effects when returned to the aquarium. The polyps were withdrawn, with tissue that appeared to be contracted or pulled down close to the skeleton. Tentacles were extended within 2 hours of return to the aquarium. They appeared to be feeding normally when fed after the experiment. Prior to the experiment, when the corals were taken from the aquarium, there was mucus on the tissue and on the epoxy on the sides of the square. After being in the manometer for eight hours, the tissue was moist but there was no mucus evident on the coral tissue or on the sides of the squares when touched.

The corals did not respire constantly but at irregular intervals for irregular amounts of time (Figure 6). There was no significant difference between colonies for overall respiration rates (colony $\mathrm{K}=0.262 \pm 0.170 \mu 1 / \mathrm{min} / \mathrm{cm}^{2}$; colony $\mathrm{L}=$ $0.145 \pm 0.017 \mu 1 / \mathrm{min} / \mathrm{cm}^{2} ;$ colony $\mathrm{M}=0.470 \pm 0.257 \mu 1 / \mathrm{min} / \mathrm{cm}^{2}$; Table 1). There was also no significant difference in the temperature treatments $\left(25^{\circ} \mathrm{C}=0.150 \pm\right.$ $0.093 \mu 1^{-1} \mathrm{~min}^{-1} \mathrm{~cm}^{-2} ; 27^{\circ} \mathrm{C}=0.271 \pm 0.204 \mu 1^{-1} \mathrm{~min}^{-1} \mathrm{~cm}^{-2}$; Figure 3) of overall respiration rates. There was no significant difference between the respiration rates measured in the first $3.5 \mathrm{hr}$ and second $3.5 \mathrm{hr}$ out of water for either temperature (Table 1). There was a significant interaction in the volume of oxygen consumed with regard to temperature and the first and second half of the time $(\mathrm{p}<.02$; Figure 7). At $25^{\circ} \mathrm{C}$ the volume consumed significantly dropped over time while at $27^{0} \mathrm{C}$ the volume remained statistically constant. 


\section{Growth Under Different Feeding Regimes}

The average buoyant weights are shown in Table 2 and Figure 8. There was no significant difference in the overall $\mathrm{CaCO}_{3}$ accretion of the corals with regard to individual colony or number of feedings per week. There was also no significant difference in $\mathrm{CaCO}_{3}$ accretion with regard to the repeated measurements for colony or feeding regime. However, the overall average calcium carbonate accretion rate was significantly lower for the period comprising 43-56 days $(\mathrm{p}<.001)$ than in the other three periods.

The difference in percent increase of the number of polyps was significant for individual colony $(\mathrm{p}<0.01)$ but not for number of times fed (Table 3$)$. Colony $\mathrm{K}$ gained significantly more polyps over the 10 weeks than the other two colonies.

The percent increase in area was significant for both parent colony $(\mathrm{p}<$ $0.001)$ and for number of times fed $(\mathrm{p}<0.00001$; Table 3$)$. Colony $\mathrm{K}$ gained a higher percentage of area than both colony L and M. Feeding the corals three times per week significantly increased their area over the other two feeding regimes. At the beginning of the experiment, there was no significant difference in the polyp density of the three feeding regimes. At the end of the 10 weeks, the polyp density of corals fed once per week was significantly higher than those fed twice per week $(\mathrm{p}<0.05$; Table 3$)$ and those fed three times per week $(\mathrm{p}<0.01)$. There was no significant difference between those fed two and three times per week. Corals fed once per week had a significant increase in polyp density from the beginning to the end of the experiment $(\mathrm{p}<0.05)$. Corals fed twice and three 
times per week showed no significant change. Colony L was significantly greater overall polyp density than the other two colonies ( $p>0.01$; Table 3 ).

\section{Explantation and Storing $5.1 \mathrm{~cm} \mathrm{M.} \mathrm{faveolata}$}

All of the M. faveolata explants appeared healthy and survived during their year in the aquaria. The growth rates of the explants from each parent colony were significantly different from the other parent colonies $(p<0.01$, Table 4$)$. After placement at Looe Key, 28 (77.8\%) corals were present after one year with no mortality although eight colonies had been physically lost. Calcium carbonate accretion of colony 1 was significantly less than colony $2(p<0.05)$ during the first year in the field. After two years in the field, 23 (63.8\%) were present. Again, several cores were lost but none were observed to have died in situ. Calcium carbonate accretion of colony 3 was significantly less than colony $2(p<0.05)$. The mean growth rate of all the explants in the aquaria was $36.4 \pm 10.5 \mathrm{mg} /$ day, $34.79 \pm 22.87 \mathrm{mg} /$ day for the first year in the field and $65.17 \pm 43.36 \mathrm{mg} /$ day for the second year in the field. Accretion in year 2 in the field was significantly greater from the other two years $(\mathrm{p}<.001$ for the first year in the field; $\mathrm{p}<.01$ for the aquarium). The accretion of $\mathrm{CaCO}_{3}$ in cores from colony $2(90.60 \pm 24.15)$ was significantly greater than colony $3(32.50 \pm 22.39 ; \mathrm{p}<0.02)$ during the second year in the field.

During the first year in the field there were no effects as to which mound the explant was placed on or effects of orientation on growth rates. However, there was a combined year and mound effect in the second year. The growth rate of RTS1b in the second year (the mound closest to open water; $87.79 \pm 42.28$ ) 
was significantly greater $(p<0.05$; Table 4$)$ than that of the first year or RTS1a $(32.74 \pm 25.56)$

A number of qualitative observations were made regarding growth morphology. Cores with epoxy at the edge of the tissue grew smoothly over the epoxy and onto the ReefMount. Cores that were epoxied at the core base but with exposed skeleton between the epoxy and tissue developed a mushroom shape, which allowed the exposed skeleton to be colonized by algae and small encrusting invertebrates. In the field, cores that were placed vertically or intermediately had most of their growth on the lower side of the core with almost no growth on the upper side. On the topside there was a layer of fine sediment and filamentous red algae. One core appeared to have white plague disease that affected $\sim 1 / 4$ of the explant area; however, it recovered. Several explants bleached to varying degrees (none severely) over the summer months of 1998 and subsequently recovered.

As of May 1999, all three donor colonies were still alive and growing. On each of the colonies some of the cores had partially grown over their epoxy plugs, while some had not (pers. com. Erich Mueller).

\section{Storing M. faveolata and $A$. cervicornis}

The $A$. cervicornis explants in the aquarium began to grow over their epoxy bases within weeks. After a month, they began to lighten in color; some had dark spots inside the calyxes. Necrosis of the tissue began within the next two weeks, beginning either at the base or the growing tip and progressing toward the opposite end. Some explants no longer had white tips, suggesting that they had ceased growing. The four explants from colony A were dead within two months. 
Those from colony B died over six months while some of the colony $\mathrm{C}$ explants survived as long as eight months (Figure 10).

A. cervicornis on the array remained healthy. After 6 months, one explant was lost. Of the remaining five branches, all but two had broken. What remained was healthy. The loss of the broken pieces rendered the volume method for growth measurement invalid. After nine months, Hurricane Georges (25 September 1998) caused a line from a lobster trap to be wrapped around the array, bending two arms and dislodging the corals. Two branches were retrieved and replaced onto the array; they were healthy as of May 1999 (18 months into the experiment).

A. cervicornis explants on the substrate remained healthy except that after six months, one branch was dead from an unknown cause, one was broken and another was missing. The remaining nine corals were dark in color, and appeared healthy with several producing new branches. After Hurricane Georges, seven were located with live tissue, including several buried in the sediment. Some had started new branches and most were dark in color. As of May 1999, seven were still alive, dark in color with new branches. The Kruskall-Wallis ANOVA shows a significant difference in that the aquarium had a lower survival rate $(0.0 \%)$ than the storage on the array $(75 \%)$ or on the substrate $(75 \%)$ after 10 months $(\mathrm{p}<$ $0.0001)$.

After 5 months, the M. faveolata cores in the aquarium began to exhibit signs of disease. Only one core had begun growing over the epoxy while the rest of the cores lost tissue, some to as few as four polyps. In several cases, the only 
visible tissue left was down in the calices of a few polyps with none of the coenosarc apparent. Three of the cores died, two from parent colony F and one from E. After seven months and the installation of an UV water sterilizer, the cores began to recover. The coenosarc reappeared and polyps reconnected. Tentacles became visible and active. After two months, the cores began to decline again and die. Three more cores died at nine months. All of colony F was then dead as were one sample from each of the other colonies (Figure 10). By July 1998, there were only three cores left, all from colony E. These were taken from the aquarium and placed at Newfound Harbor (RTS3).

The twelve M. faveolata cores on the array remained healthy, with tissue growing over the epoxy, until August 1998 (12 months into the experiment) when Hurricane Georges hit. Then nine remained. As of May 1999, eight were present. Most of these had grown over the epoxy and most of the ReefMounts.

M. faveolata cores on the substrate at RTS3 were all present and healthy until May 1998 when three were observed to be missing. The remaining cores were observed to be healthy at that time. Three of the ReefMounts were broken and needed replacement. The cores were taken back to the PKMRC, repaired, and returned the following day. After Hurricane Georges, only one core was left. Its ReefMount had a broken stem that had been repaired with duct tape and had been wedged into the hole. This core had a dead spot, possibly due to injury during the storm. The tissue was growing over the epoxy on all but a small section. This core remained there until May 1999 when it was transferred to the array at RTS2. There was notably more tissue covering the ReefMounts of the cores kept on the 
array than the core that had been at RTS3. A lost core was found a few days later in the surrounding rubble with live tissue and also moved to the array. The Kruskall-Wallis ANOVA showed a significantly higher survival rate of the corals on the array $(66.0 \%)$ than in the other two treatments $(25 \%$ for the aquarium and $0.8 \%$ for the substrate; $\mathrm{p}<0.0001$ ).

As of August 1999, all three donor colonies of M. faveolata were still alive but in varying degrees of health. Parent colony D had 9 core holes that could be recognized. Two of these exhibited growth over the epoxy plugs, which appeared as dimples in the tissue. The rest of the cores that could be identified had grown smaller and seemed to be continuing to heal. The surrounding tissue was 3 $-5 \mathrm{~mm}$ above the level of the epoxy. There was a dead spot, approximately $28 \mathrm{~cm}$ $\mathrm{x} 10 \mathrm{~cm}$, that could have included the three missing core holes. There was no sign of the epoxy in this area. There was also no obvious reason for the dead spot. The colony had been visited in July 1998 (10 months after the cores were done) at which time there had been no sign of any tissue loss. Colonies $\mathrm{E}$ and $\mathrm{F}$ appeared healthy. One core hole could not be located on colony E. Three of the wounds were healed to dimples and the rest showed that the tissue was advancing with the exception of one hole where an encrusting worm had enlarged the area. Colony $\mathrm{F}$ had four holes completely grown over that were barely evident. Five holes were partially grown over and three were the original size. Of those three, two had large encrusting worms living on the epoxy. 
The donor colonies of $A$. cervicornis were not relocated. However, subsequent visits to the donor reef area showed a marked reduction in the $A$. cervicornis population (pers. obs.).

\section{No Maintenance Storing of Acroporids}

The accretion of calcium carbonate by all explants of $A$. cervicornis in the field $(38.59 \pm 12.16 \mathrm{mg} /$ day; Table 5$)$ was not significantly greater than in the $\operatorname{tank}(24.29 \pm 8.85 \mathrm{mg} /$ day $)$ and there was no significant difference between the two colonies. There was also no significant difference in linear extension between the field $(40.15 \pm 9.98 \mathrm{~mm})$ and the tank $(31.38 \pm 12.57 \mathrm{~mm})$, however; maximum basal width was significantly greater $(p<0.00001)$ in the tank $(56.00 \pm$ $4.42 \mathrm{~mm})$ than in the field $(27.52 \pm 2.30 \mathrm{~mm})$. There was no intercolony difference with respect to linear extension/growth $(\mathrm{p}>0.05)$.

The accretion of calcium carbonate of the A. palmata in the field (111.86 $\pm 30.70 \mathrm{mg} /$ day $)$ was significantly greater $(\mathrm{p}<0.01)$ than that in the tank $(64.62 \pm$ $14.74 \mathrm{mg} /$ day $)$. There was also a significant difference $(\mathrm{p}<0.001)$ in linear extension between the field $(40.68 \pm 9.85 \mathrm{~mm})$ and the tank $(16.18 \pm 5.48 \mathrm{~mm})$. As seen with $A$. cervicornis, the maximum basal diameter was much greater $(\mathrm{p}<$ $0.0001)$ in the tank $(84.40 \pm 12.46 \mathrm{~mm})$ than in the field $(44.53 \pm 8.54 \mathrm{~mm})$. There were no significant differences between the two colonies in any of the measured parameters.

One $A$. cervicornis branch died, apparently soon after placement into the open water system since it exhibited no growth. Three of the A. cervicornis branches were broken on the array: one was completely lost, one had been broken 
down to a short stub, and the third was found in the sand and was matched to its base.

The A. cervicornis explants placed in the tank had little or no branching while those on the array formed 2-6 branches. The basal growth of the explants in the tank was very extensive while the basal growth in the field was minimal. This trend was also observed with $A$. palmata.

The explants were returned to the reefs where collected.

\section{DISCUSSION}

\section{Respiration in Sub-Aerial Conditions}

The intermittent nature of the respiration of coralsdemonstrated in this study is not without precedent. Barnhart and McMahon (1987) point out that a wide variety of animals, including hibernating mammals (Bickler 1984), reptiles (Ackerman and White 1979; Glass and Johansen 1979; Hicks and Reidesel 1983), and resting or dormant insects (Miller 1974; Edney 1978) demonstrate some type of periodic or intermittent $\mathrm{CO}_{2}$ release. Aestivating snails of have been shown to have discontinuous respiration (Herreid 1977; Barnhart and McMahon 1987; Churchill and Storey 1989; Storey and Storey 1990; Hermes-Lima et al. 1998). So, too, have the pupae of large saturniid moths (Miller 1974; Edney 1978).

The only reference found in which respiration of a coral was measured out of water (Romaine et al. 1997) did not find intermittent respiration in the airexposed coral Stylophora pistillata, although, it could have been missed due to the methodology. In their experimental procedure respiration was not measured continuously and flushing of the Infra-Red Gas Analyzer chamber could have 
negated a possible trigger for intermittent respiration. S. pistillata is a branching, shallow water species that may have adapted to exposure to air differently than the mounding $M$. faveolata, which tends to be in deeper waters where exposure does not occur. The difference in methodology of maintaining the moisture of the corals (humidity maintained over $90 \%$ vs. seawater in the bag with little air space) may have triggered different responses. Romaine et al. (1997) ran their experiment for only 4 hours. If intermittent gas exchange occurs in S. pistillata, it may take longer than 4 hours to commence.

Effects of Intermittent Gas Exchange - Intermittent gas exchange involves a buildup of $\mathrm{CO}_{2}$ in the tissues of the coral (Romaine et al. 1997). The partial pressures would involve a larger amount of $\mathrm{CO}_{2}$ than $\mathrm{O}_{2}$ because the capacity of body fluids is much higher for $\mathrm{CO}_{2}$ in tissue (Dejours 1981). This means that a change in the mode of respiration may only slightly affect $\mathrm{O}_{2}$ content in the tissue but cause a prolonged period of net $\mathrm{CO}_{2}$ release or accumulation in the body fluids. This would account for the intermittent readings in this experiment. $\mathrm{CO}_{2}$ accumulation in the tissue might lower cellular metabolism (Barnhart and McMahon 1987) by lowering intercellular pH (Burton 1976; Barnhart 1986b; Barnhart and McMahon 1987). However, Storey and Storey (1990) point out that quiescence, a torpor-like state, tends to set in quickly in relation to the change in $\mathrm{CO}_{2}$ concentration. They suggest that this condition may facilitate continued metabolic depression. Barnhart and McMahon (1987) also suggest that lowered metabolism may induce hypoventilation in snails and would cause $\mathrm{CO}_{2}$ accumulation. 
There have been many studies of coral respiration (McCloskey et al. 1978) in P/I curve studies (Chalker 1981; Chalker et al. 1983; Leletkin, et al. 1993), while examining carbon or nitrogen budgets (Coles and Jokiel 1977; Muscatine et al. 1981; Davies 1984; Szmant-Froelich and Pilson 1984) and while assessing the effects of changing conditions or stresses on the corals of several different species (Davies 1980; McCloskey and Muscatine 1984; Porter et al. 1984; Anderson et al. 1986; Muthiga and Szmant 1987; Abdel-Salam and Porter 1988; Edmunds and Davies 1988; Patterson et al. 1991; Telesnicki and Goldberg 1995).

Studies of aerial respiration of marine organisms are so far limited to intertidal invertebrates as reviewed by Shick et al. (1988). Bivalves have reduced oxygen consumption while exposed to air (Shick et al. 1988; Demers and Guderley 1994) as does the sea anemone Anthopleura elegantissima (Shick and Dykens 1984) and the giant clam Tridacna gigas (Mingoa-Licuanan 1993). Intertidal barnacles go into quiescence (Barnes and Barnes 1957) while limpets vary in their response depending on species, size and location on the shore (Branch et al 1988).

Transporting corals by the dry method has its limits. Since there is no photosynthesis or food consumption the time out of water should be limited to the extent of the reserve energy in the coral tissue. M. faveolata did well for 8 hours with no mortality. Carlson $(1987,1999)$ has successfully shipped corals using the dry method for up to 24 hours. Desiccation, even in a high humidity environment, would also be limiting. Romaine et al. (1997) showed reduced weight due to water loss in a three hour experiment in an environment with a humidity $>90 \%$. 
By wrapping the corals in plastic bags in this experiment, desiccation may have been minimized by restricting the amount of air space for water exchange. The corals in this experiment were not moved. However, while on a boat, there could be much movement. While in transit under these conditions, the $10-20 \mathrm{ml}$ of seawater would have moved about and probably remoistened the tissue.

When removed from the manometers, the corals seemed to be devoid of mucus (i.e., none came off the tissue when touched). It would seem reasonable to expect with the reduction in metabolic rate would come a corresponding reduction in mucus production. There is evidence that a mucus coating, while useful in preventing desiccation, would also be a barrier to $\mathrm{CO}_{2}$ and $\mathrm{O}_{2}$ exchange. Shephard (1994) found a $30 \%$ reduction in gas exchange in fish with mucus covered gills. If this were also true with corals, it may be to their advantage to stop producing mucus so as to facilitate increased gas exchange and mitigate some of the $\mathrm{CO}_{2}$ accumulation in the tissues rather than continue to produce mucus to prevent desiccation.

Any measurement that could have been the product of anything other than the respiration of the coral was disregarded (i.e., temperature or barometric pressure changes). Consequently, the amount of respiration is probably underestimated. The volume of $\mathrm{O}_{2}$ consumed was probably underestimated because there was $2-3 \mathrm{~mm}$ between the end and the first mark on the pipette so that small amount was not included in the calculations. Also, there were a few occasions where the soap bubble popped in the middle of a measurement. A new bubble would be immediately started but the measurement would be below the 
true value. The passing of occasional summer storms also influenced the readings of barometric pressure. While it is possible to make a manometer that is not affected by changing barometric pressure, this experiment was underway when the storms became a potential problem. In any event, a closed design would not mimic the conditions of the dry method transport as well as the design used. There was, however, enough respiration time without such complications to be confident in the results of the experiment.

It would be best to repeat this experiment with better instrumentation, either an $\mathrm{O}_{2}$ probe or an IRGA. This would make constant measurements more accurate and complete. The manometer was sensitive enough for this experiment. However, the manometer made it difficult to record complete data since it had to be watched constantly and recorded manually for eight hours.

Having two separate pieces of coral in the chamber, even if they were from the same parent colony, was probably a confounding factor. The two pieces were used to increase the surface area to ensure that there was enough respiration to register on the manometer.

\section{Growth Under Different Feeding Regimes}

The increased polyp density observed with low feeding frequentcies may be a mechanism to increase the colony's chances of obtaining more plankton when food is scarce. It could theoretically take more energy to make polyps than coenosteum because of the more complex structure of the polyps. If this were so, there would have to be a reason to use resources to increase polyp density such as increasing the ability to capture prey. Corals capturing enough food to grow may 
be spending their energy more on space competition and not increasing food intake. If prey availability affects polyp density then examining the polyp density of coral skeleton may give clues to the food availability to that coral at different time frames.

One colony in the experiment (colony $\mathrm{K}$ ) had significantly more growth in area and number of polyps. This demonstrates that these aspects of growth may have a genetic component and may be something to consider when choosing donor colonies. Another possible factor affecting how fast explants increase in area or make new polyps may be their location on the donor colony. In this experiment the fragments were all cut from skirt fragments less than a third of a meter from the edge. Some of the fragments were cut from the very thin (less than $2 \mathrm{~cm}$ thick) edge of the skirts suggesting that these polyps were relatively young compared to the pieces cut from tissue further from the edge, where the skirt was more than $10 \mathrm{~cm}$ thick. Young polyps may have an accelerated growth rate, especially those on the edge that are in direct competition with surrounding species. It is possible that colony $\mathrm{K}$, just due to circumstances of the shape/configuration of the skirt fragments collected, had more samples from the edge than the other two colonies. However, the original placement of the samples was not documented so this variable could not be tracked here.

It would be necessary to test individual species for their optimum feeding regime since the relative contribution of captured prey and zooxanthellate products to the energy needs of corals appears to vary from species to species (Johannes et al. 1970; Porter 1976). It may be necessary to investigate the 
nutritionally optimum zooplankton to feed corals as well, since Szmant-Froelich and Pilson (1980) point out that some Artemia sp. are more nutritional than others. Corals in the field have almost certainly a more diverse diet. Schauer et al. (1979) and Porter (1974) showed that up to nine phyla have been found in the gut contents of various species. These prey animals probably vary in nutritional value and biochemical makeup possibly making some more important than others or some combination of animals necessary for optimum growth. Yonge and Nichols (1931) and Porter (1978) found that corals digest their food in 3 to 13 hours. This means that each polyp may capture prey at least daily. Daily feedings may optimize the growth rates but may "overfeed" the aquarium if the excess food is not filtered out after each feeding opportunity.

The amount fed and frequency of feeding may be important. SzmantFroelich and Pilson (1984) found $A$. danae fed 3x/week grew three times faster than corals fed the weekly amount all at once. For this species there may be a limit to how much can be consumed and utilized in a given period of time. By spreading the availability of food out over the week the coral may be able to optimize nutrient intake. In a similar experiment, Szmant-Froelich and Pilson (1980) found that freshly collected corals had tissue composition (lipid/protein ratios, carbohydrate and zooxanthellae content) more similar to corals fed $3 \mathrm{x} /$ week than the other feeding regimes. This suggests that corals provided with zooplankton feed often.

The use of two flow regimes when feeding the corals was probably unnecessary as little prey capture probably occured when the water was still. The 
Artemia are capable of avoidance behavior and were probably not coming into contact with tentacles until the power heads began providing an oscillating water flow providing for more favorable prey capture by the corals. Corals have more successful prey capture in moving water than in still (Helmuth and Sebens 1993; Johnson and Sebens 1993; Sebens et al. 1997). The corals in this experiment were mostly flat and horizontal except for later in the experiment when the tissue advanced over the sides of the squares. Helmuth and Sebens (1993) showed that Agaricia agracities in its horizontal plate form were able to feed over the entire area of the colonies. Behavior observations suggested that currents originating within the polyps aided the particle capture. Flow was necessary to deliver the prey to the colony and the corals were probably able to capture prey even though most of their polyps were not in the turbulent sides. Johnson and Sebens (1993) showed that flat corals had lower capture rates downstream. The oscillating water in the aquariums appeared to increase plankton capture within and between the corals.

If the water had been kept still for a prolonged period it may have created a health problem for the corals. Patterson (1985) found that water motion affects photosynthesis and respiration in M. annularius as did Dennison and Barnes (1988) in Acorpora formosa. Jokiel (1978) showed that water motion affected growth, mortality and reproduction of several coral species. The lack of water motion affects $\mathrm{CO}_{2}$ and $\mathrm{O}_{2}$ exchange (Jokiel 1978). 


\section{Storing M. faveolata and $A$. cervicornis}

Each storage method investigated here has advantages as well as disadvantages. Closed aquaria allow corals to be maintained under controlled, and potentially optimized, conditions. The usefulness of the closed aquaria was demonstrated with the successful storage of the $5.1 \mathrm{~cm}$ cores of $M$. faveolata in experiment 1 . Although conditions such as temperature and light may not have been optimal, growth rates, as measured by buoyant weight increase, were comparable to those measured at offshore reef locations. Aquaria can also be used for culture, growing small corals to a size that is amenable for transplantation. Compared to field storage, corals can be more easily monitored. Another advantage to keeping corals in aquaria is a reduction in fouling and the explants require much less cleaning to weigh than cores that have been in the field, either on an array or on the substrate. This reduces spatial competition and appears to allow the corals to increase surface area more rapidly.

Disadvantages of closed aquaria include the fact that they require the highest amount of maintenance and impose the highest monetary and time cost of the three options examined here. They require daily monitoring and frequent cleaning. If pathogenic organisms are introduced, as may have occurred when new M. faveolata cores were added, the closed system may become an incubation chamber for disease. It is also possible that the pathogenic organisms were present all along but that conditions became stressful for corals or favorable for the pathogen. The closed system may also lead to concentrated levels of pathogens, thus helping to overcome coral defenses. Such problems occurred after other 
corals had been successfully housed in the aquaria in previous experiments so this was not a persistent problem but an incidental one. The infected aquarium has since been broken down, sterilized, and successfully restarted; corals have been introduced with no sign of disease recurring. A remedy for this potential problem may be a quarantine tank for observation of disease signs and, possibly, preventive treatment.

The corals that lost tissue did not display signs of previously described diseases. The malady affecting $A$. cervicornis was somewhat like white-band disease (WBD) except that tissue loss sometimes started at the colonial tips, not always at the base as described by Gladfelter, et al. (1977). However, Precht and Aronson (1977) describe WBD as progressing "usually from the base to tip" but give no further description of other patterns. Tissue loss was also much slower than usually reported for white-band. In M. faveolata it took several weeks to go over $2.5 \mathrm{~cm}$ cores, leaving isolated patches of tissue. These signs were unlike any diseases described thus far. The presence of folliculinids on the M. faveolata may be an indication of increased bacterial levels in the aquarium since folliculinids consume bacteria. Increased bacteria levels may have been either the source or the result of disease. Folliculinids have not been implicated in any disease state previously described although they have been found associated with diseased corals in the field (D. Santavy, per. com).

The open-water system at Lee Stocking Island worked very well for storage of acroporids although growth rates were generally lower than in the field. With only routine system maintenance, all but one coral survived and appeared to 
be healthy. However, there are considerations that must be taken into account before using an open seawater system. The seawater source must be of high quality, as was the case at Lee Stocking Island. Experience with open seawater systems in the Florida Keys has shown that the systems are not suitable for yearround maintenance of reef corals. The temperature of near-shore waters in the Keys varies beyond the tolerances of reef corals (Mueller, per. com., per. obs). Salinity variation and periods of high turbidity are also problematic. Unless specifically treated, the incoming seawater provides continual opportunities for pathogens to be introduced into the system in the seawater.

The arrays elevated the corals from the substrate, thereby reducing the potential for sand scour, predation and competition. One of the $5.1 \mathrm{~cm}$ cores and a few of the A. cervicornis explants on the reef substrate showed signs of competition with adjacent gorgonians and other benthic organisms in the form of tissue retraction where the organisms touched. The $A$. cervicornis colonies were moved but those of $M$. faveolata could not be. However, arrays are vulnerable to fishing lines and lobster trap lines moved about during storms as evidenced by the array on Looe Key that had to be repaired twice. The survival rate of the $2.5 \mathrm{~cm}$ cores on the array was $100 \%$ until Hurricane Georges. In another investigation that used the same type of array, $5.1 \mathrm{~cm}$ cores of $M$. faveolata had survival rates of $83.3 \%$ in nearshore waters and $91.7 \%$ in offshore waters over a year (Cook et al. in press; Table 6). These survival rates suggest that arrays, especially offshore, may be useful for the short to long-term storage of Montastraea and, probably, other massive coral species. That the arrays at RTS2 and in the Bahamas had a 
slight movement in the surge that may have contributed to the breakage of acroporids.

Neither the 5.1 nor the $2.5 \mathrm{~cm}$ cores of $M$. faveolata cores were permanently attached to the substrate so the direct transplant approach was not fully tested. The cores were not securely attached because of the growth measurement techniques used (i.e. buoyant weight and volume). Using adequate amounts of epoxy would have increased the retention rates of the explants placed directly on the substrate. The same applies to the A. cervicornis in experiment 3 . Placing A. cervicornis on the substrate (at $6 \mathrm{~m}$ depth) using the Key Largo limestone blocks was successful to a point. This method is best for very shortterm storage (days to weeks) during calm conditions.

The variance in calcium carbonate accretion by all three species examined was greater in the field than in the aquarium or open seawater system. However, in the first year in the field, three explants lost mass, as did two in the second year. Even though the cores were within meters of each other, there may have been slight differences in environments. Some bleached more than others did, some were initially affected by fish grazing while those nearby were not, and a few were affected by gorgonians touching them. Despite this, the overall growth rate in the second year in the field accelerated over the two previous years. The difference probably has little to do with the storage strategy but is probably a consequence of the increasing perimeter and surface area. Variance is also expected to increase as faster growing explants accelerate in their growth rate. 
This highlights the importance of using corals of equal size (diameter and area) over relatively short periods of time for testing various conditions.

Finally, a difference was found between the two RTS1 sites. Even though the mounds were only $7.1 \mathrm{~m}$ apart, corals on the mounds with closest proximity to the open water grew faster, perhaps due to hydrodynamic conditions or plankton availability, there is also the possibility that the difference may simply be an artifact of the low sample size.

\section{Donor Survival}

For M. faveolata, the survival of the donor colonies was $100 \%$ for both core sizes taken. This demonstrates that this type of fragmentation can be used successfully and still maintain the topographical complexity and biological function of the donor site. There was no obvious reason for the dead spot on colony D. The colony had been examined in July 1998 and there was no sign of any tissue loss so it is unlikely that the coring caused the necrosis. The explants from colony D succumbed to the disease in the aquaria.

Partial tissue loss from injury is normal in the life of a coral (Porter 1972; Woodley et al. 1981; Bythell et al. 1993; Knowlton et al. 1981; Fishelson 1973; Glynn 1988; Bak and Van Eys 1975). The regeneration capabilities of corals suggest that they have adapted to the common occurrence of small lesions (Meesters et al. 1996; Meesters et al. 1997). Meesters et al. (1997) found that tissue regeneration is initially fast, then slows over time. This would explain the partial covering of the epoxy in both core hole sizes. Normally the quick regeneration of tissue would be important because algae and other organisms, 
including bioeroders, will colonize any area of skeleton left uncovered. The bioeroders would undermine the health and, possibly, the life of the colony. However, epoxy over the exposed skeleton prevents bioeroders from entering. One core hole was expanded apparently by the presence of an encrusting worm. The tissue may eventually grow over the worm and its hard casing will still prevent bioerosion.

Meesters et al. (1997) found that M. annularis would regenerate a maximum of $4.7 \mathrm{~mm}^{2}$ of tissue for every $\mathrm{mm}$ of wound perimeter. The $2.54 \mathrm{~cm}$ core has a $99.8 \mathrm{~mm}$ circumference and an area of $791.7 \mathrm{~mm}^{2}$. The $5.1 \mathrm{~cm}$ core leaves a hole $179.5 \mathrm{~mm}$ in circumference and $2565.2 \mathrm{~mm}^{2}$ in area. Assuming that similar regeneration rates apply to $M$. faveolata, the smaller hole would leave $322.8 \mathrm{~mm}^{2}$ unregenerated after a year and the larger hole would leave 1721.5 $\mathrm{mm}^{2}$ unregenerated. This agrees with observations of the tissue surrounding the core holes in this experiment (no direct measurements were taken). Ten months into the experiment the holes were well on their way to closing but had not progressed much further in most cases when observed 23 months after the cores were taken. These observations suggest that the recovery/regeneration rates and profiles of M. faveolata and M. annularis are similar. The area of the wound is maximized in this case because of its circular shape. Bak and Stewart van Es (1980) found that if a lesion exceeds a certain size (different for each species) the tissue would not regenerate. The $5 \mathrm{~cm}^{2}$ core may be in the range of that size for M. faveolata. A better approach may be to take the explants from the edge of the 
skirt of the colony to create what Meesters et al. (1996) refer to as a type II lesion (not completely surrounded by tissue as in type I) by breaking off the edge. This may result in a more rapid replacement of the explanted tissue. The use of epoxy to patch the skeleton, making the area unavailable to bioeroders, would mitigate any disadvantage in competition caused by taking the explant from the coral.

When using coring to explant corals, it may be wise to consider the stresses the donor colony may undergo after explantation. Regeneration rates are reduced by temperature-related bleaching (Meesters and Bak 1993) and sedimentation (Meesters et al. 1992), probably due to the extra demands on energy that these stresses cause. Explants should not be taken in the month or two before a spawning event because regeneration reduces the energy available for reproduction (Van Venghel and Bak 1994). The method described in this paper may be useful for the explant of species other than those studied here, but baseline research would be required. Different species differ in their capacity for regeneration (Bak 1983; Meesters et al. 1992; Bak and Meesters 1996), and there may be species for which would be inappropriate.

As noted above, the donor colonies of $A$. cervicornis were not relocated. The decline of $A$. cervicornis in the Florida Keys has been so dramatic in the last few years that the Florida Keys National Marine Sanctuary has severely limited issuance of permits for its collection. The acroporids are under consideration for addition to the list of endangered species in North America.

The donor colonies of $A$. palmata in the Bahamas appeared healthy and were continuing to grow. This demonstrates that explantation of a coral species 
that reproduce primarily by fragmentation is a reasonable option for restoration purposes. Most importantly, it fulfills the goal of minimizing the impact to the donor site and maintaining the complexity of the substrate.

\section{Morphology}

Growth morphology was affected by reattachment orientation. In the field, M. faveolata cores that were placed in vertical or intermediate orientations on the substrate had more growth on the lower side. The upward-facing surfaces were covered with filamentous red algae and a substantial layer of fine sediment, either of which, or both, may have inhibited the tissue from advancing. All explants in aquaria and on the arrays were maintained horizontally so the effect of the environment in relation to the angle of attachment was not tested.

In the no-maintenance storage experiment, the colony morphologies of both $A$. cervicornis and A. palmata were strongly affected by how they were stored. Basal growth was significantly higher in the seawater system than on the array for both species. This suggests that by placing explants in such a facility the bases would become more secure in a few months, thus adding to the chances of successful explantation.

There are several possible explanations for the morphological responses. The first difference is water flow (unidirectional vs. oscillatory). Both species exhibited more branching in the field than samples held in the aquarium. Branching in an oscillatory environment may increase propagation because of increased breakage from wave energy. Branching fragments survive and produce a new colony, by keeping part of the fragment slightly off the bottom and 
reducing its tendency to roll. Another possible explanation is related to the light regimes. In the tank, the corals were exposed to direct sunlight only around noon; the tank walls and the heavy screening (which was fouled with algae), blocked direct light during the morning and afternoon. Also, the tank was black and did not reflect light. Growing a wide horizontal base may optimize light capture where under these conditions. On the reef, the corals were exposed to irradiance from all directions. Branching may allow a more efficient capture of scattered light. Finally, the presence of large numbers of snails in the tanks (unidentified ceriths) may have encouraged the basal growth by removing all potentially competing algae. This is consistent with aquarium observations where the reduction of competition for space appears to encourage lateral growth. On the other hand, A. palmata calcified more in the field than in the tank, an effect that could not be determined for $A$. cervicornis as breakage and death excluded three samples.

\section{Effects of Fragment Size}

There appeared to be no difference in survival of the two different sized cores although these experiments did not provide rigorous testing of the minimum viable size (Table 6). The smaller $(2.5 \mathrm{~cm})$ cores survived well except where mechanical loss occurred, and in the aquaria. This was probably a result of circumstance rather than a size effect. Thus, the smallest viable size is probably smaller than the $2.5 \mathrm{~cm}$ tested here. However, smaller sizes would be expected to make the explants more vulnerable to predation by corallivores, non-selective grazers and spatial competition. Also, there is probably little value in deploying 
explants of smaller size (except see the previous discussion regarding healing of donor colonies).

\section{ReefMounts}

The design of the ReefMounts made it easy to handle cores without touching live tissue. ReefMounts fit readily into inexpensive and easily made PVC racks when maintained in open or closed aquarium systems. This design makes it necessary to drill holes into the substrate for field deployment but allows for a secure emplacement on virtually any angle (assuming that sufficient amounts of epoxy are used). The design also allows corals to grow over the edge onto surrounding substrate with a natural look.

The ReefMounts were made of the same standard ceramic material but were acquired from two different sources, a commercial ceramics shop in Alabama and a local craft shop in Marathon, FL. However, due to differences in the casting processes, we did experience structural problems with those from one of the sources. The ReefMounts were hollow and broke easily where the stem joined the top. This breakage accounted for virtually all of the losses in experiment 3. This problem was nonexistent in experiment 1 where the better quality (solid) mounts were used.

\section{Growth Measurements}

The buoyant weight method was used in two experiements. This provides a sensitive and well-accepted measure of calcification (Jokiel, 1978; Dodge et al., 1984; Davies, 1989). However, this method also requires retrieving the cores and making measurements with a very stable balance (i.e. on land or on a large ship). 
Thorough removal of encrusting algae and other biota is also necessary and can be a time-consuming task. Buoyant weight is inappropriate for corals placed permanently on the reef for restoration for obvious reasons, but may be appropriate to track the growth of corals while in storage in aquaria or in the field if they have the capability of being retrieved. Measurement of linear extension is only one aspect of growth as are basal growth, thickening, or branching. These individual measurements are important for interpreting the types of growth but provide only a partial picture, whereas change in buoyant weight integrates all types of skeletal accretion.

Volumetric measurement was attempted in the comparative storage method experiment as a means of obtaining an integrated measure of growth in the field but was found to be problematic. The M. faveolata cores grew too slowly for an accurate measurement of growth. The signal-to-noise ratio was very low and no discernible growth was detected. This method may have utility but it is essential that minimum-sized vessels be used for a given coral. In the case of $A$. cervicornis, branches broke and were lost onto the reef during the experiment making it impossible to repeat measurements. Even if they did not break, branching would make it necessary to use larger vessels, further decreasing the signal-to-noise ratio.

\section{Conclusions}

The research reported here provides new information with respect to the potential effects of size of $M$. faveolata explants and different storage methods for corals. Although I did not determine the minimum viable size for $M$. faveolata, 
use of explants less than $2.5 \mathrm{~cm}$ in diameter is probably impractical. Direct transplantation subjects the explant to only one move, which minimizes opportunity for injury, and is relatively low in cost and maintenance. However, the explants are subject to loss if the corals are not securely attached. Arrays are useful for storage and culture of explants. Arrays can reduce competitive and predatory pressures and protect from sand scour. They require lower maintenance and cost than aquaria (but higher than direct transplantation). Arrays are susceptible to damage from lines because they are raised above the rest of the substrate. Storage in aquaria is an option for holding and culturing corals. Aquarium storage reduces encrustation on epoxy and ReefMounts and can provide conditions for optimum growth. Bacterial infection is a potential factor in aquariums. Aquaria require higher maintenance and cost than do arrays and direct transplantation.

In summary, I found: 1) all three species examined here recovered and grew after explantation, 2) the type of storage facility and orientation of cores affects morphology of all three species, 3) the "dry method" works well for transportation, 4) epoxies do not appear to be toxic, 5) increased feeding decreases the polyp density and increases growth rate and 6) M. faveolata explants will survive as small as $2.5 \mathrm{~cm}$ in diameter. 
Table 1. Measurements of respiration of $M$. faveolata in a manometer under the conditions of being transported by the dry method.

\begin{tabular}{|c|c|c|c|c|c|c|}
\hline & & \multicolumn{4}{|c|}{ Respiration Rate $(\mu \mathrm{l} / \mathrm{min} / \mathbf{c m} 2)$} & \\
\hline & \multicolumn{2}{|l|}{ 1st Half } & \multicolumn{2}{|l|}{ 2nd Half } & \multicolumn{2}{|l|}{ Total } \\
\hline & 25 & 27 & 25 & 27 & 25 & 27 \\
\hline Colony $\mathrm{K}$ & $0.104 \pm 0.071$ & $0.506 \pm 0.406$ & $0.115 \pm 0.162$ & $0.188 \pm 0.185$ & $0.131 \pm 0.122$ & $0.262 \pm 0.170$ \\
\hline Colony L & $0.171 \pm 0.043$ & $0.212 \pm 0.063$ & $0.174 \pm 0.115$ & $0.137 \pm 0.037$ & $0.158 \pm 0.058$ & $0.145 \pm 0.017$ \\
\hline Colony $\mathbf{M}$ & $0.116 \pm 0.056$ & $0.461 \pm 0.291$ & $0.013 \pm 0.022$ & $0.337 \pm 0.187$ & $0.169 \pm 0.092$ & $0.470 \pm 0.257$ \\
\hline Overall & $0.127 \pm 0.061$ & $0.392 \pm 0.295$ & $0.099 \pm 0.116$ & $0.222 \pm 0.164$ & $0.150 \pm 0.093$ & $0.289 \pm 0.216$ \\
\hline & & \multicolumn{4}{|c|}{ Volume Oxygen Consumed $(\mu \mathrm{l} / \mathrm{cm} 2)$} & \\
\hline Colony $\mathrm{K}$ & $11.24 \pm 11.15$ & $6.41 \pm 2.41$ & $2.07 \pm 4.63$ & $6.40 \pm 7.33$ & $13.31 \pm 12.95$ & $12.81 \pm 8.78$ \\
\hline Colony $\mathbf{L}$ & $9.07 \pm 5.60$ & $8.13 \pm 1.25$ & $7.12 \pm 6.91$ & $10.79 \pm 4.25$ & $16.19 \pm 6.12$ & $18.92 \pm 4.32$ \\
\hline Colony M & $7.21 \pm 4.22$ & $4.20 \pm 2.36$ & $0.23 \pm 0.45$ & $8.85 \pm 5.73$ & $7.43 \pm 4.54$ & $13.05 \pm 6.78$ \\
\hline \multirow[t]{2}{*}{ Overall } & $9.35 \pm 7.69$ & $6.23 \pm 2.48$ & $2.72 \pm 4.93$ & $8.78 \pm 5.57$ & $12.07 \pm 9.30$ & $15.01 \pm 6.82$ \\
\hline & & \multicolumn{4}{|c|}{ Time of Respiration (min) } & \\
\hline Colony $\mathrm{K}$ & $64.2 \pm 39.1$ & $18.3 \pm 12.3$ & $20.0 \pm 28.2$ & $19.5 \pm 19.1$ & $72.2 \pm 51.8$ & $37.8 \pm 8.8$ \\
\hline Colony $\mathrm{L}$ & $51.7 \pm 23.1$ & $41.1 \pm 14.2$ & $47.2 \pm 59.9$ & $71.5 \pm 9.0$ & $98.9 \pm 38.3$ & $\begin{array}{c}* * 112.6 \pm \\
22.8 \\
\end{array}$ \\
\hline Colony $\mathbf{M}$ & $45.8 \pm 30.7$ & $12.6 \pm 12.2$ & $6.0 \pm 8.5$ & $22.0 \pm 16.5$ & $48.8 \pm 34.8$ & $* * 34.6 \pm 19.3$ \\
\hline Overall & $55.0 \pm 31.3$ & $23.8 \pm 16.7$ & $27.6 \pm 41.3$ & $36.8 \pm 27.6$ & $71.1 \pm 44.3$ & $60.6 \pm 39.2$ \\
\hline
\end{tabular}


Table 2. The average buoyant weights and gains of $5 \mathrm{~cm}^{2}$ Montastraea faveolata samples cut from three different colonies and under three different feeding regimes (once, twice, and three times per week).

\begin{tabular}{|c|c|c|c|c|c|}
\hline \multirow[b]{3}{*}{ Colony } & \multicolumn{5}{|c|}{ Average Buoyant Weight (g) } \\
\hline & \multicolumn{5}{|l|}{ Day } \\
\hline & $\underline{\mathbf{0}}$ & $\underline{28}$ & $\underline{42}$ & $\underline{56}$ & $\underline{70}$ \\
\hline $\mathrm{K}$ & $41.32 \pm 8.09$ & $\overline{42.48} \pm 8.29$ & $\overline{42.81} \pm 8.18$ & $\overline{43.06} \pm 8.16$ & $\overline{43.72 \pm 7.93}$ \\
\hline $\mathrm{L}$ & $40.20 \pm 11.20$ & $40.92 \pm 11.68$ & $41.26 \pm 11.72$ & $41.46 \pm 11.88$ & $42.31 \pm 11.36$ \\
\hline $\mathrm{M}$ & $39.40 \pm 6.71$ & $39.85 \pm 6.50$ & $40.11 \pm 6.31$ & $40.33 \pm 6.18$ & $40.71 \pm 6.13$ \\
\hline Overall & $40.30 \pm 8.65$ & $41.08 \pm 8.88$ & $41.39 \pm 8.83$ & $41.62 \pm 8.86$ & $42.24 \pm 8.58$ \\
\hline \multicolumn{6}{|l|}{ Times } \\
\hline \multicolumn{6}{|l|}{ Fed/Week } \\
\hline $1 \mathrm{X}$ & $41.13 \pm 7.44$ & $41.58 \pm 7.06$ & $41.82 \pm 6.88$ & $41.96 \pm 6.75$ & $41.12 \pm 7.25$ \\
\hline $2 \mathrm{X}$ & $41.74 \pm 11.55$ & $42.67 \pm 12.29$ & $42.81 \pm 12.35$ & $43.02 \pm 12.48$ & $43.34 \pm 11.87$ \\
\hline \multirow[t]{2}{*}{$3 \mathrm{X}$} & $38.04 \pm 6.38$ & $38.99 \pm 6.51$ & $39.55 \pm 6.49$ & $39.86 \pm 6.55$ & $42.85 \pm 6.00$ \\
\hline & \multicolumn{5}{|c|}{ Average Weight Gain (mg/day) } \\
\hline Colony & $\underline{1-28}$ & $\underline{29-42}$ & $\underline{43-56}$ & $\underline{57-70}$ & Overall \\
\hline $\mathrm{K}$ & $41.48 \pm 21.01$ & $23.57 \pm 45.63$ & $17.78 \pm 25.59$ & $47.01 \pm 34.78$ & $34.26 \pm 12.21$ \\
\hline $\mathrm{L}$ & $25.80 \pm 41.95$ & $24.53 \pm 26.15$ & $14.27 \pm 34.15$ & $60.25 \pm 76.01$ & $30.13 \pm 19.49$ \\
\hline $\mathrm{M}$ & $15.93 \pm 10.28$ & $19.18 \pm 17.49$ & $15.26 \pm 11.99$ & $27.55 \pm 8.89$ & $18.77 \pm 11.06$ \\
\hline Overall & $27.74 \pm 28.96$ & $22.43 \pm 31.16$ & $15.77 \pm 24.89$ & $44.94 \pm 49.05$ & $27.72 \pm 15.77$ \\
\hline \multirow{2}{*}{\multicolumn{6}{|c|}{$\begin{array}{l}\text { Times } \\
\text { Fed/Week }\end{array}$}} \\
\hline & & & & & \\
\hline $1 \mathrm{X}$ & $16.09 \pm 20.64$ & $17.34 \pm 24.40$ & $9.85 \pm 19.40$ & $41.40 \pm 35.63$ & $27.66 \pm 11.06$ \\
\hline $2 X$ & $33.39 \pm 39.11$ & $10.13 \pm 40.74$ & $14.79 \pm 34.79$ & $59.48 \pm 76.25$ & $31.54 \pm 16.19$ \\
\hline $3 X$ & $33.73 \pm 22.16$ & $39.82 \pm 17.64$ & $22.67 \pm 17.14$ & $33.56 \pm 14.64$ & $23.66 \pm 20.30$ \\
\hline
\end{tabular}


Table 3. Polyp count, area change and polyp density of $5 \mathrm{~cm}^{2}$ samples of $M$. faveolata from three colonies and under three different feeding regimes (once, twice and three time per week). Colony $\mathrm{K}$ had a significantly greater increase ( $\mathrm{p}<$ 0.01 ) in the percent increase of polyps than the other two colonies but there was no significant increase in polyp count for feeding regime. Colony $\mathrm{K}$ had a significantly greater increase $(\mathrm{p}<0.01)$ in area than the other two colonies and corals fed three times per week had a significantly greater increase $(p<0.00001)$ in area than the other two colonies. Polyp density significantly increased ( $p<$ 0.05 ) in corals fed once per week.

\begin{tabular}{|c|c|c|c|c|}
\hline \multirow[b]{2}{*}{ Colony } & \multicolumn{2}{|c|}{ Polyp Count } & \multirow[b]{2}{*}{ CHANGE } & \multirow[b]{2}{*}{$\%$ CHANGE } \\
\hline & PRE & POST & & \\
\hline $\mathrm{K}$ & $150.4 \pm 11.3$ & $201.8 \pm 17.2$ & $51.4 \pm 22.3^{* *}$ & $35.1 \pm 17.6$ \\
\hline $\mathrm{L}$ & $210.8 \pm 29.4$ & $251.4 \pm 29.3$ & $40.7 \pm 17.2$ & $19.9 \pm 9.6$ \\
\hline $\mathrm{M}$ & $161.2 \pm 17.7$ & $191.0 \pm 21.6$ & $29.8 \pm 16.6$ & $18.9 \pm 10.9$ \\
\hline Overall & $174.1 \pm 33.5$ & $214.8 \pm 34.9$ & $40.6 \pm 20.4$ & $24.6 \pm 14.8$ \\
\hline \multicolumn{5}{|l|}{ TIMES } \\
\hline \multicolumn{5}{|l|}{ FED/WEEK } \\
\hline $1 \mathrm{X}$ & $173.3 \pm 28.7$ & $212.3 \pm 32.9$ & $39.0 \pm 22.1$ & $23.4 \pm 14.7$ \\
\hline $2 \mathrm{X}$ & $179.8 \pm 44.7$ & $223.4 \pm 40.4$ & $43.6 \pm 22.9$ & $26.8 \pm 18.6$ \\
\hline $3 \mathrm{X}$ & $169.3 \pm 27.4$ & $208.1 \pm 33.7$ & $38.8 \pm 18.0$ & $23.5 \pm 12.0$ \\
\hline Colony & \multicolumn{2}{|c|}{$\operatorname{Area}\left(\mathrm{cm}^{\wedge} 2\right)$} & & \\
\hline $\mathrm{K}$ & $25.41 \pm 2.14$ & $29.45 \pm 3.06$ & $4.04 \pm 3.12$ & $16.33 \pm 13.10$ \\
\hline $\mathrm{L}$ & $26.86 \pm 1.76$ & $31.85 \pm 5.26$ & $9.43 \pm 4.80$ & $34.75 \pm 17.08^{* *}$ \\
\hline $\mathrm{M}$ & $25.16 \pm 1.86$ & $29.69 \pm 3.78$ & $4.53 \pm 4.17$ & $18.63 \pm 18.35$ \\
\hline Overall & $25.81 \pm 2.02$ & $31.81 \pm 5.34$ & $6.00 \pm 4.68$ & $23.24 \pm 17.90$ \\
\hline \multicolumn{5}{|l|}{ TIMES } \\
\hline \multicolumn{5}{|l|}{ FED/WEEK } \\
\hline $1 \mathrm{X}$ & $25.31 \pm 2.03$ & $28.29 \pm 2.17$ & $2.98 \pm 1.80$ & $12.06 \pm 7.71$ \\
\hline $2 X$ & $26.58 \pm 2.10$ & $31.85 \pm 5.26$ & $5.27 \pm 4.18$ & $19.56 \pm 15.11$ \\
\hline $3 \mathrm{X}$ & $25.55 \pm 1.86$ & $35.29 \pm 5.61$ & $9.75 \pm 4.80$ & $38.09 \pm 18.46^{* *}$ \\
\hline Colony & \multicolumn{3}{|c|}{\begin{tabular}{|c|} 
Polyp Density (polyps/cm²) \\
\end{tabular}} & \\
\hline $\mathrm{K}$ & $5.95 \pm 0.64$ & $6.91 \pm 0.82$ & $0.95 \pm 1.08$ & \\
\hline $\mathrm{L}$ & $7.85 \pm 1.03$ & $7.02 \pm 0.90$ & $-0.83 \pm 0.83$ & \\
\hline $\mathrm{M}$ & $6.41 \pm 0.58$ & $6.49 \pm 0.84$ & $0.08 \pm 0.66$ & \\
\hline Overall & $6.74 \pm 1.11$ & $6.81 \pm 0.86$ & $0.07 \pm 1.12$ & \\
\hline \multicolumn{5}{|l|}{ TIMES } \\
\hline \multicolumn{5}{|l|}{ FED/WEEK } \\
\hline $1 \mathrm{X}$ & $6.64 \pm 1.06$ & $7.16 \pm 0.91$ & $0.53 \pm 1.03^{*}$ & \\
\hline $2 X$ & $6.69 \pm 1.01$ & $6.75 \pm 0.68$ & $0.06 \pm 0.97$ & \\
\hline $3 \mathrm{X}$ & $6.89 \pm 1.33$ & $6.51 \pm 0.91$ & $-0.38 \pm 1.25$ & \\
\hline
\end{tabular}


Table 4. $\mathrm{CaCO}_{3}$ accretion (normalized to $\mathrm{mg} /$ day) for the $5.1 \mathrm{~cm}$ (2") cores of Montastraea faveolata after approximately one year in an aquarium and then two consecutive years in the field. Year 2 in the field was significantly different from the other two years $(\mathrm{p}<$ 0.001 for field, year $1, \mathrm{p}<0.01$ for the aquarium). The second year on mound $b$ was significantly greater than the first year on either mound $(\mathrm{p}<0.05)$. There were no effects of orientation of placement.

\begin{tabular}{|c|c|c|c|c|c|c|}
\hline \multirow{3}{*}{ Colony } & \multicolumn{6}{|c|}{ Calcium Carbonate Accretion } \\
\hline & \multirow{2}{*}{$\begin{array}{l}\text { Aquarium } \\
\text { mean } \pm \mathrm{sd}\end{array}$} & \multirow[b]{2}{*}{$\mathrm{n}$} & \multicolumn{2}{|c|}{ Field (Year 1) } & \multicolumn{2}{|l|}{ Field (Year 2) } \\
\hline & & & mean \pm sd & $\mathrm{n}$ & mean $\pm \mathrm{sd}$ & $\mathrm{n}$ \\
\hline 1 & $45.85 \pm 8.62$ & $12 * *$ & $19.93 \pm 24.58$ & $9 *$ & $51.21 \pm 60.58$ & 6 \\
\hline 2 & $36.92 \pm 5.12$ & $12 * *$ & $46.60 \pm 15.77$ & $12 *$ & $90.60 \pm 24.15$ & $11^{*}$ \\
\hline 3 & $26.27 \pm 6.56$ & $12 * *$ & $33.45 \pm 21.72$ & 7 & $32.50 \pm 22.39$ & $6^{*}$ \\
\hline \multirow[t]{2}{*}{ Combined } & $36.35 \pm 10.54$ & 36 & $34.79 \pm 22.872$ & 28 & $65.17 \pm 43.36$ & $23 * * *$ \\
\hline & $\begin{array}{lll}3 & 2 & 1\end{array}$ & & $13 \quad 2$ & & $\begin{array}{lll}3 & 1 & 2\end{array}$ & \\
\hline \multicolumn{7}{|l|}{ Mound } \\
\hline$a$ & & & $32.74 \pm 25.56$ & 12 & $45.03 \pm 35.56$ & 11 \\
\hline b & & & $37.18 \pm 18.47$ & 16 & $87.79 \pm 42.28$ & $12 *$ \\
\hline
\end{tabular}

* $\mathrm{p}<0.05$

$* * \mathrm{p}<0.01$

$* * * \mathrm{p}<0.001$ 
Table 5. Growth of Acropora cervicornis and A. palmata branches that were stored in an open sea water system and in the field.

\begin{tabular}{|c|c|c|c|c|c|c|c|c|}
\hline & & \multirow{2}{*}{\multicolumn{3}{|c|}{$\begin{array}{l}\text { Acropora palmata } \\
\text { Field }\end{array}$}} \\
\hline & \multicolumn{3}{|c|}{$\begin{array}{l}\text { Acropora cervicornis } \\
\text { Tank }\end{array}$} & \multicolumn{2}{|c|}{ Tank } & & & \\
\hline & mean & $\mathbf{n}$ & mean & $\mathbf{n}$ & mean & n & mean & n \\
\hline Measurement & & & & & & & & \\
\hline $\begin{array}{c}\mathrm{CaCO3} \\
\text { accretion } \\
\text { (mg/day) }\end{array}$ & $24.29 \pm 8.85$ & 5 & $38.59 \pm 12.16$ & $4 \mathrm{~ns}$ & $64.62 \pm 14.74$ & 6 & $111.86 \pm 30.70$ & $6^{* *}$ \\
\hline $\begin{array}{c}\text { Vertical } \\
\text { Extension } \\
(\mathbf{m m})\end{array}$ & $31.38 \pm 12.57$ & 5 & $40.15 \pm 9.98$ & $4 \mathrm{~ns}$ & $16.18 \pm 5.48$ & 6 & $40.68 \pm 9.85$ & $\begin{array}{c}6 * * \\
*\end{array}$ \\
\hline Maximum & $56.00 \pm 4.42$ & 5 & $27.52 \pm 2.30$ & $5 * *$ & $84.40 \pm 12.46$ & 6 & $44.53 \pm 8.54$ & $6 * *$ \\
\hline Basal Growth & & & & $\begin{array}{c}* * \\
*\end{array}$ & & & & $* *$ \\
\hline & Colony A & & Colony B & & olony A & & Colony B & \\
\hline & mean & $\mathrm{n}$ & mean & $\mathrm{n}$ & mean & $\mathrm{n}$ & mean & $\mathrm{n}$ \\
\hline \multicolumn{9}{|l|}{ Measurement } \\
\hline $\begin{array}{c}\mathrm{CaCO3} \\
\text { accretion } \\
\text { (mg/day) }\end{array}$ & $33.62 \pm 15.63$ & 5 & $26.92 \pm 6.66$ & $4 \mathrm{~ns}$ & $73.45 \pm 21.84$ & 6 & $103.03 \pm 38.69$ & $6 \mathrm{~ns}$ \\
\hline $\begin{array}{c}\text { Vertical } \\
\text { Extension } \\
(\mathbf{m m})\end{array}$ & $41.20 \pm 11.43$ & 5 & $27.88 \pm 7.85$ & $4 \mathrm{~ns}$ & $30.83 \pm 20.51$ & 6 & $26.03 \pm 7.28$ & $6 \mathrm{~ns}$ \\
\hline $\begin{array}{c}\text { Maximum } \\
\text { Basal Growth } \\
(\mathrm{mm}) \\
\end{array}$ & $43.52 \pm 14.61$ & 5 & $40.00 \pm 17.63$ & $5 \mathrm{~ns}$ & $62.40 \pm 18.52$ & 6 & $66.53 \pm 28.78$ & $6 \mathrm{~ns}$ \\
\hline
\end{tabular}

$$
\begin{aligned}
& * * \mathrm{p}<0.01 \\
& * * * \mathrm{p}<0.001 \\
& * * * * \mathrm{p}<0.0001 \\
& * * * * * \mathrm{p}<0.00001
\end{aligned}
$$


Table 6. The percentage of corals surviving in three different treatments and in two sizes.

\begin{tabular}{|c|c|c|c|c|}
\hline \multirow[b]{2}{*}{ Treatment } & \multirow[b]{2}{*}{ Location } & \multirow{2}{*}{$\begin{array}{c}\text { period } \\
\text { (months) }\end{array}$} & \multicolumn{2}{|c|}{ Size } \\
\hline & & & $2.5 \mathrm{~cm}$ & $5.1 \mathrm{~cm}$ \\
\hline \multicolumn{5}{|l|}{ Transplant } \\
\hline & †Looe Key & 22 & & \\
\hline & $\begin{array}{l}\ddagger \text { Newfound } \\
\text { Harbor }\end{array}$ & 8 & $* 75.0$ & $* 63.8$ \\
\hline & & 14 & $* 8.3$ & \\
\hline \multicolumn{5}{|l|}{ Array } \\
\hline & $\S$ Tennessee Reef & 12 & & 91.7 \\
\hline & $\S$ Channel \#5 & 12 & & 83.3 \\
\hline & $\dagger$ Looe Key (RA) & 8 & 100.0 & \\
\hline & & 14 & $* 75.5$ & \\
\hline \multicolumn{5}{|l|}{ Aquarium } \\
\hline & $\dagger$ & 10 & & 100.0 \\
\hline & $\ddagger$ & 8 & 25.0 & \\
\hline
\end{tabular}

$\dagger$ Cores from experiment 1 .

$\ddagger$ Cores from experiment 3 .

$\S$ Cores from Cook et al (1999, submitted).

* All of the cores still present were alive. 


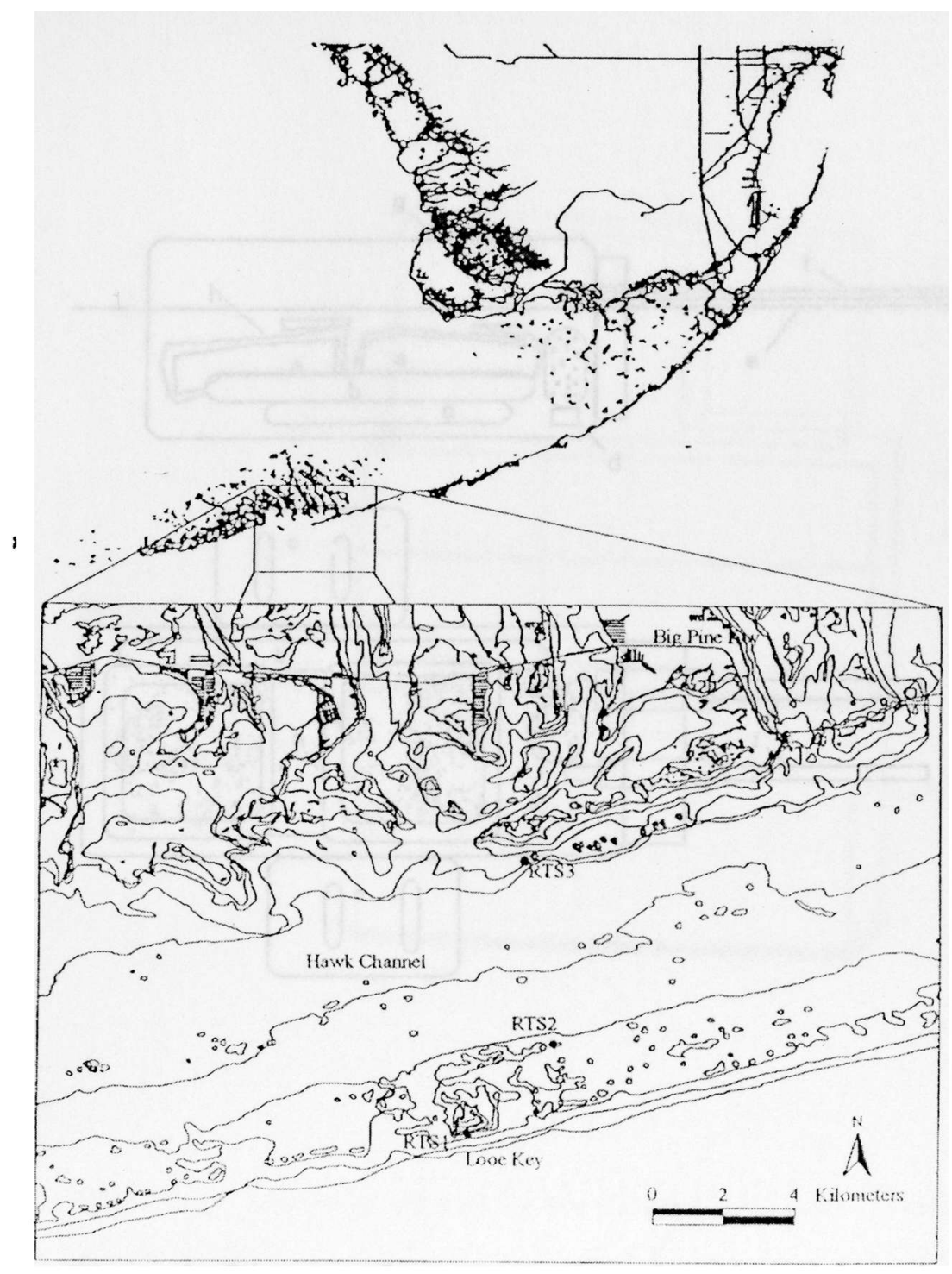

Figure 1. Map showing locations of Florida Keys restoration test sites (Bahamas site not shown). The explantation and holding of $M$. faveolata was conducted at Restoration Test Site 1 (RTS1), at Looe Key Reef. The experiment for storing and explanting of $M$. faveolata and A. cervicornis employed both RTS2, in the Looe Key Special Use Zone, and RTS3, in the Newfound Harbor Sanctuary Preservation Area. All were located in the Florida Keys National Marine Sanctuary. 

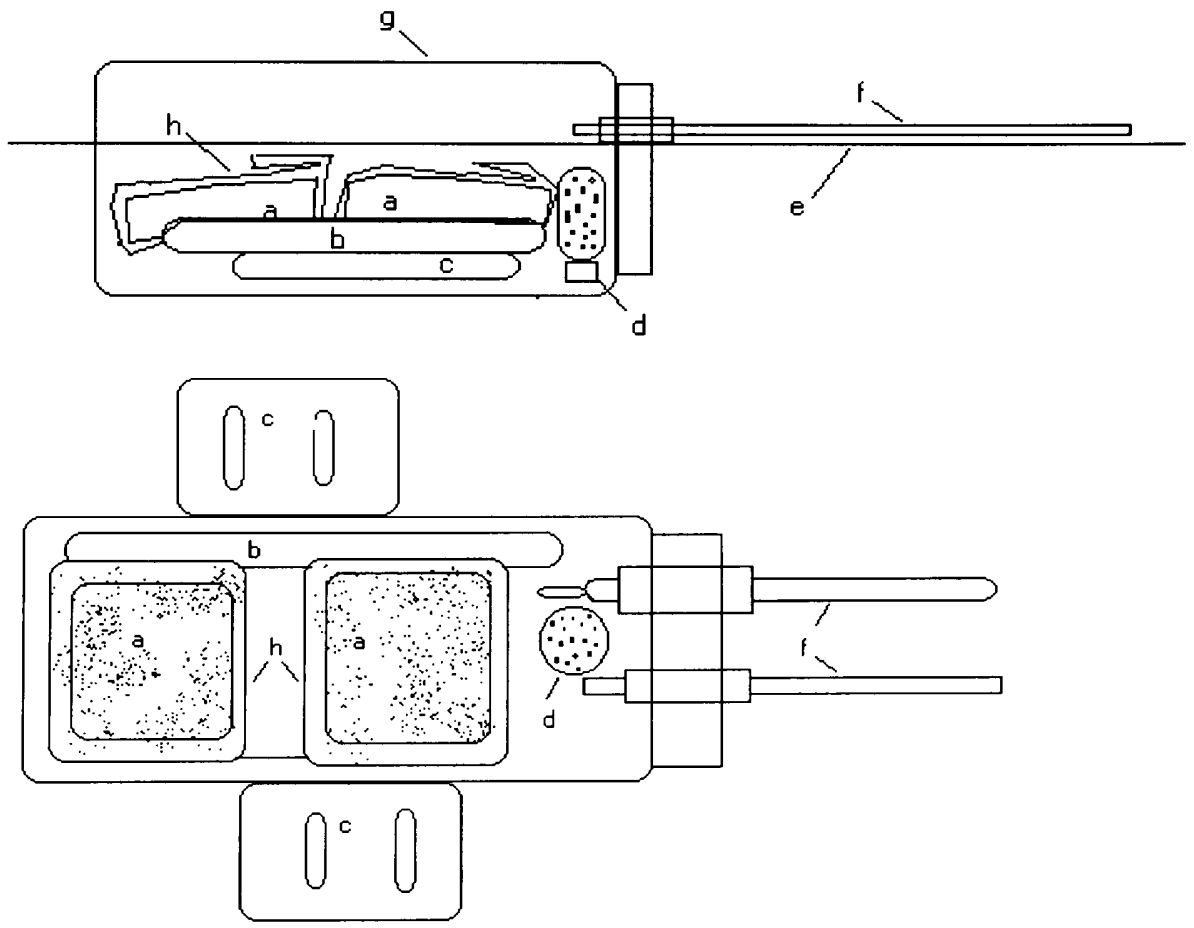

Figure 2. Diagram of manometer from the side and from the top where a) coral square, b) temperature logger, c) lead weight, d) plastic vial with holes and filled with soda lime, e) water line of water bath, f) thermometer and glass pipette, g) glass jar covered with aluminum tape to block light and $h$ ) plastic bags around coral square. 


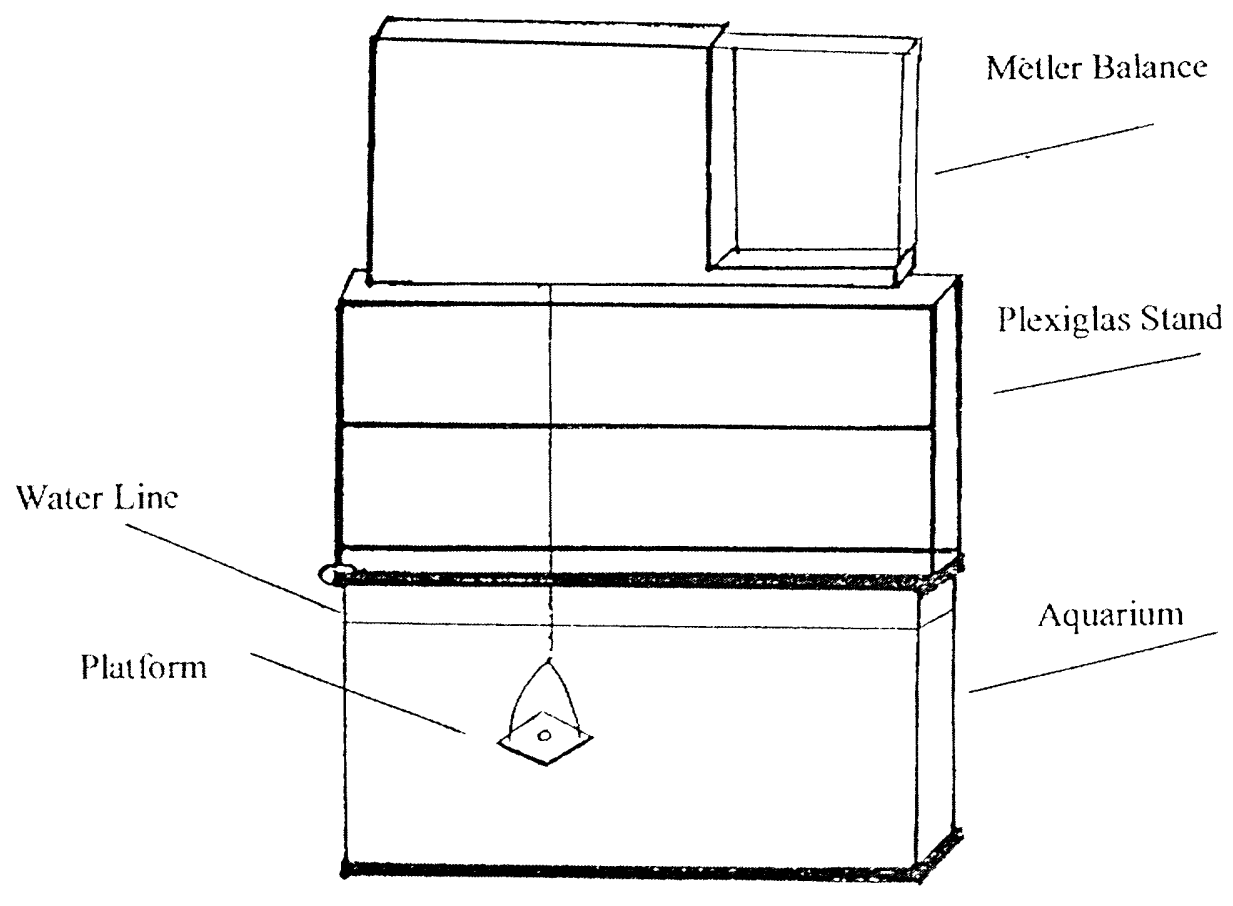

Figure 3. Diagram of the buoyant weight set up. The coral explant was placed on the platform hanging in the water in the aquarium. The walls of the Plexiglas stand minimized water movement caused by air movement. 


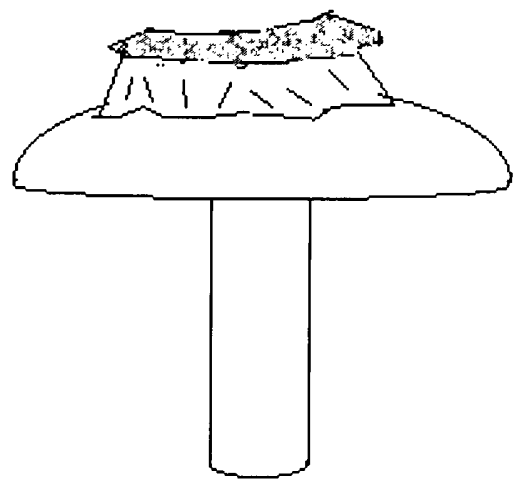

Figure 4. Cartoon of a coral attached to a ReefMount ${ }^{\mathrm{TM}}$ developed by Dr. Erich Mueller. 


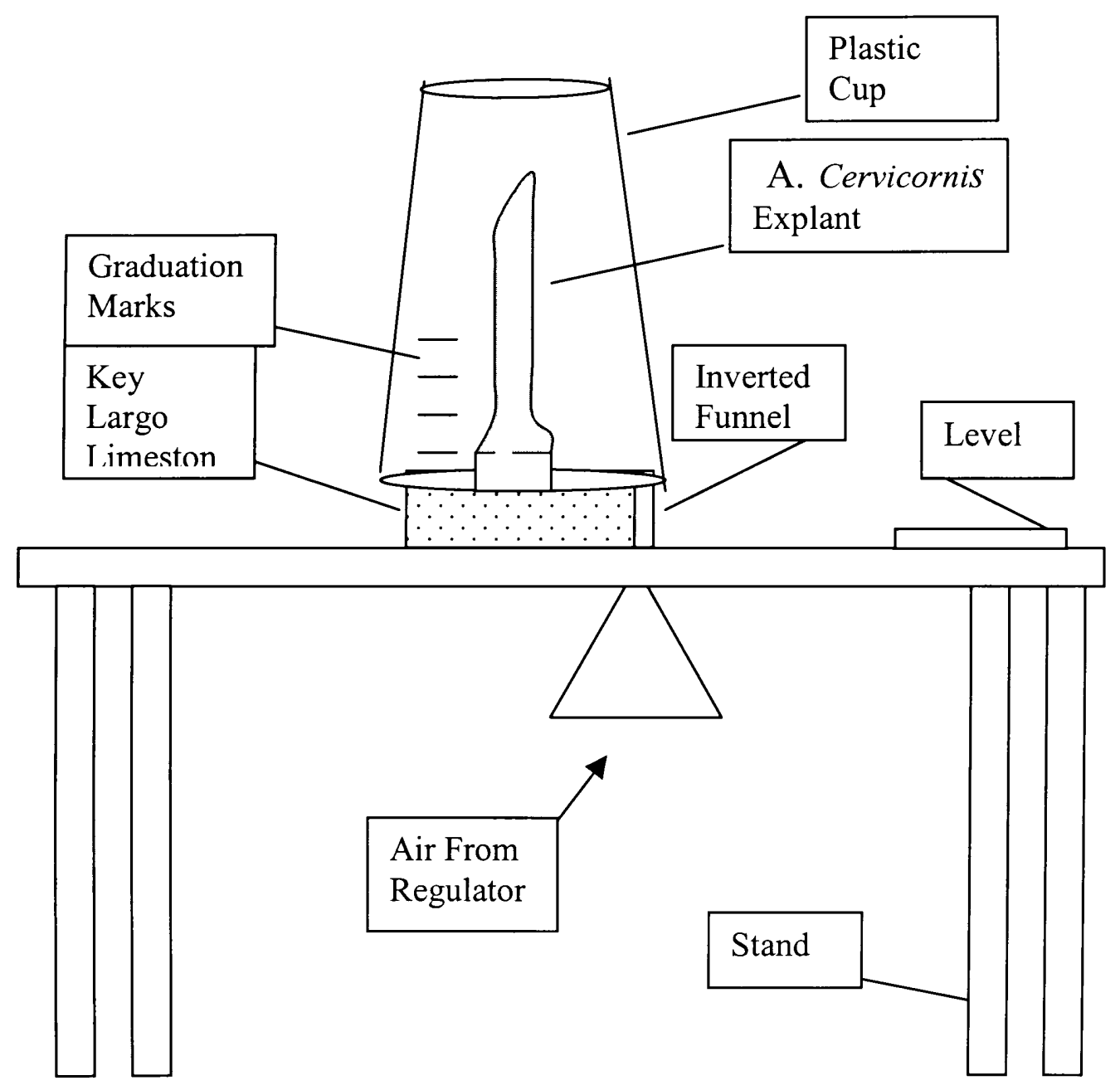

Figure 5. Volume measuring device used to measure the volume of corals while still underwater. 


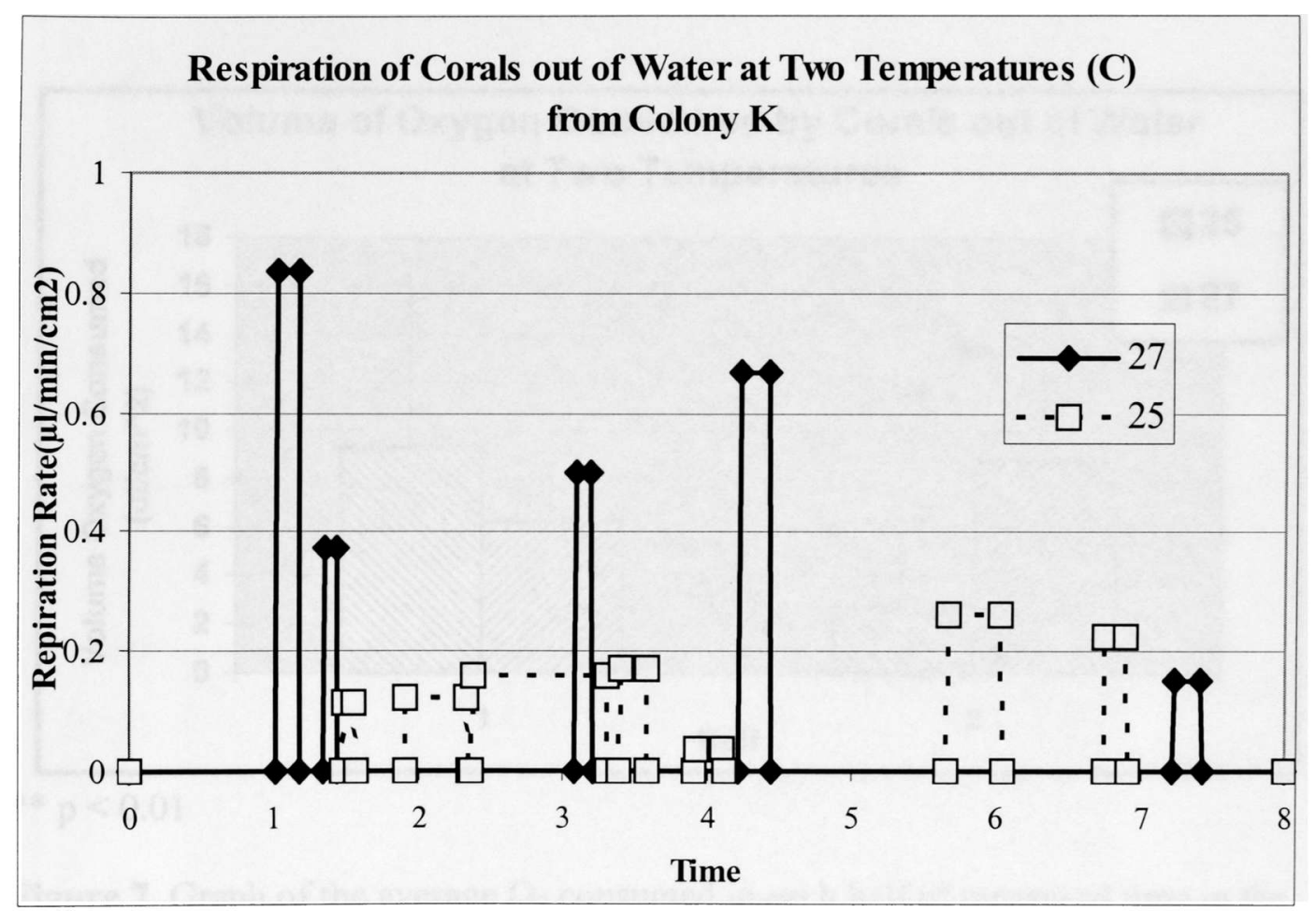

Figure 6. Graph showing the respiration rates over time on the same two coral explants at 25 and $27^{\circ} \mathrm{C}$. 


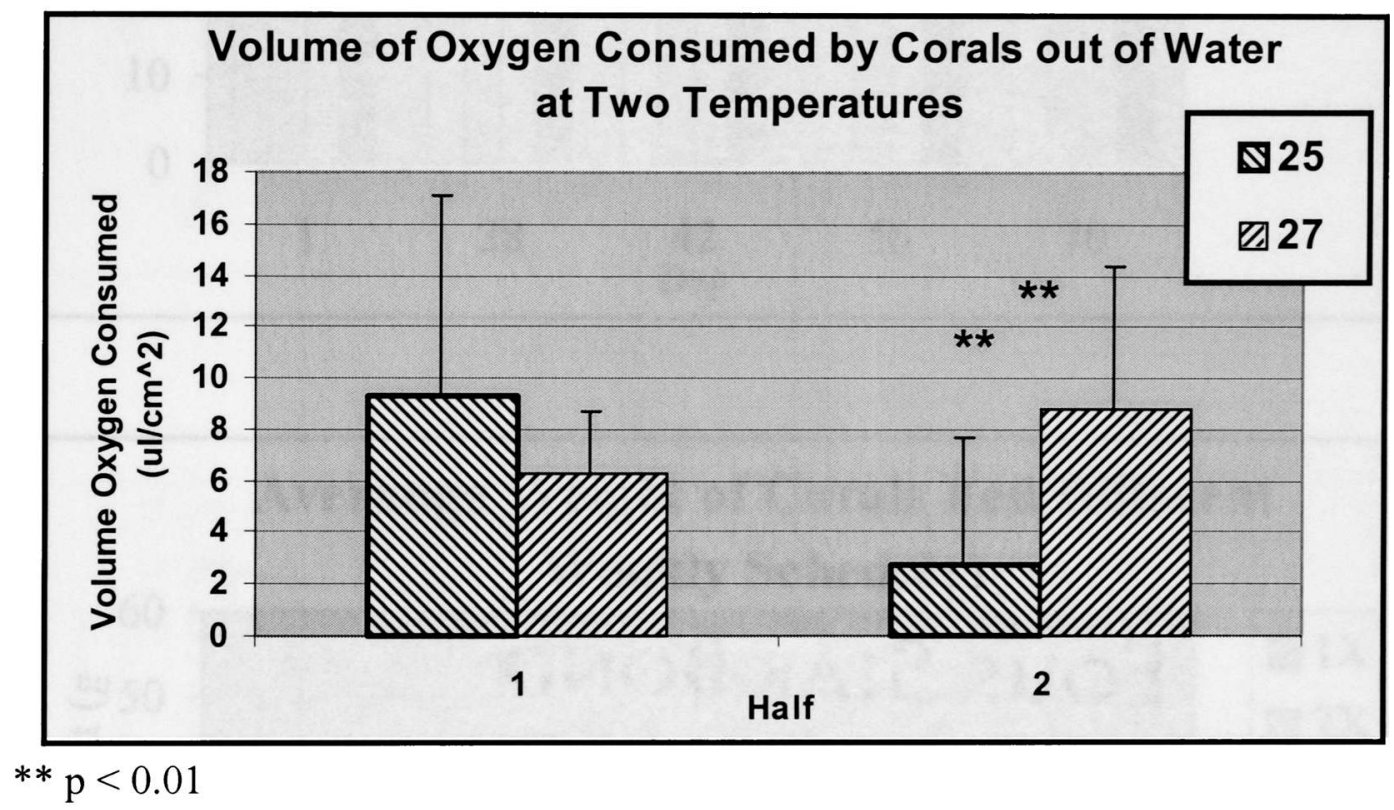

Figure 7. Graph of the average $\mathrm{O}_{2}$ consumed in each half of measured time in the manometer. The second half of time showed a significant difference in $\mathrm{O}_{2}$ consumed from the first half of measured time and for both temperatures. 


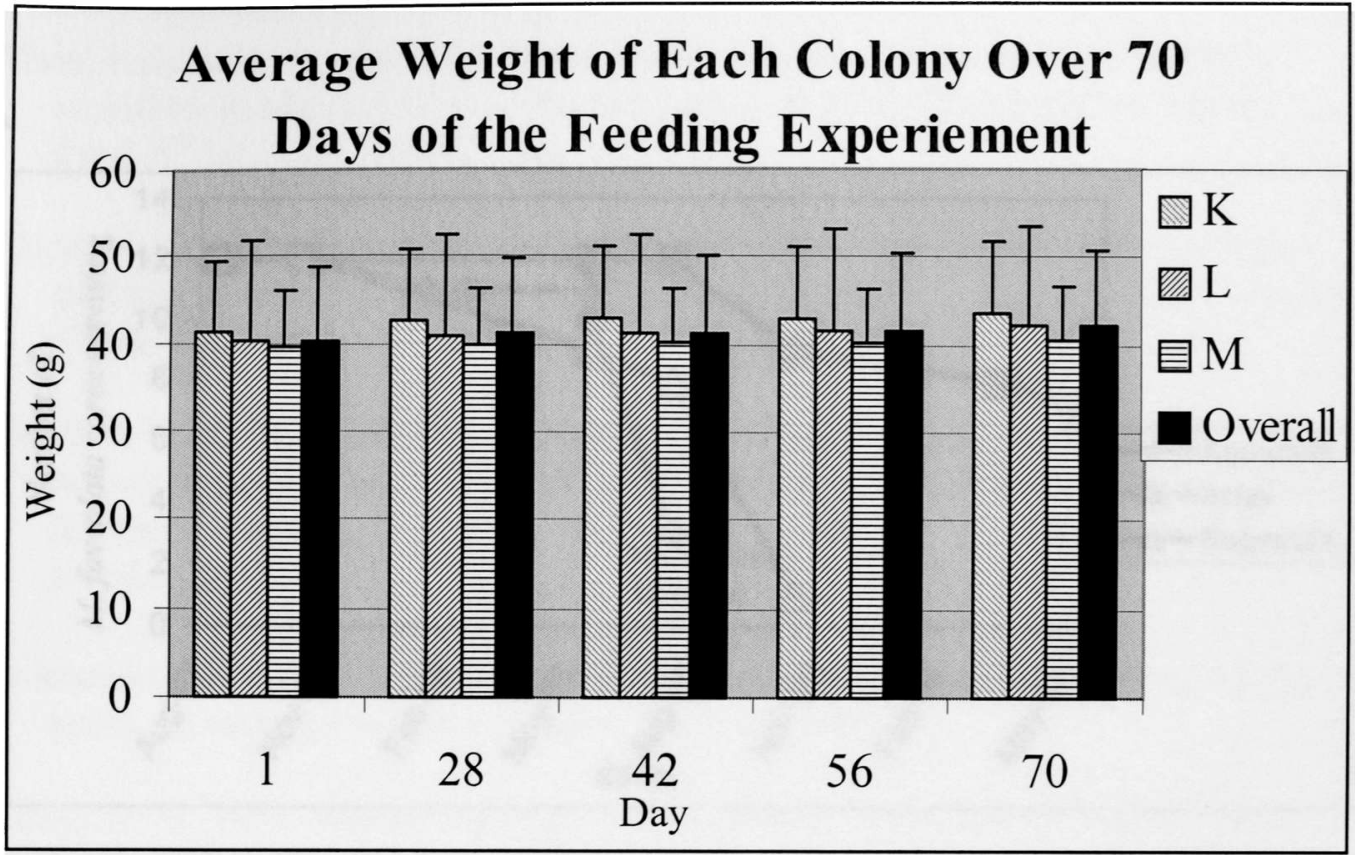

B

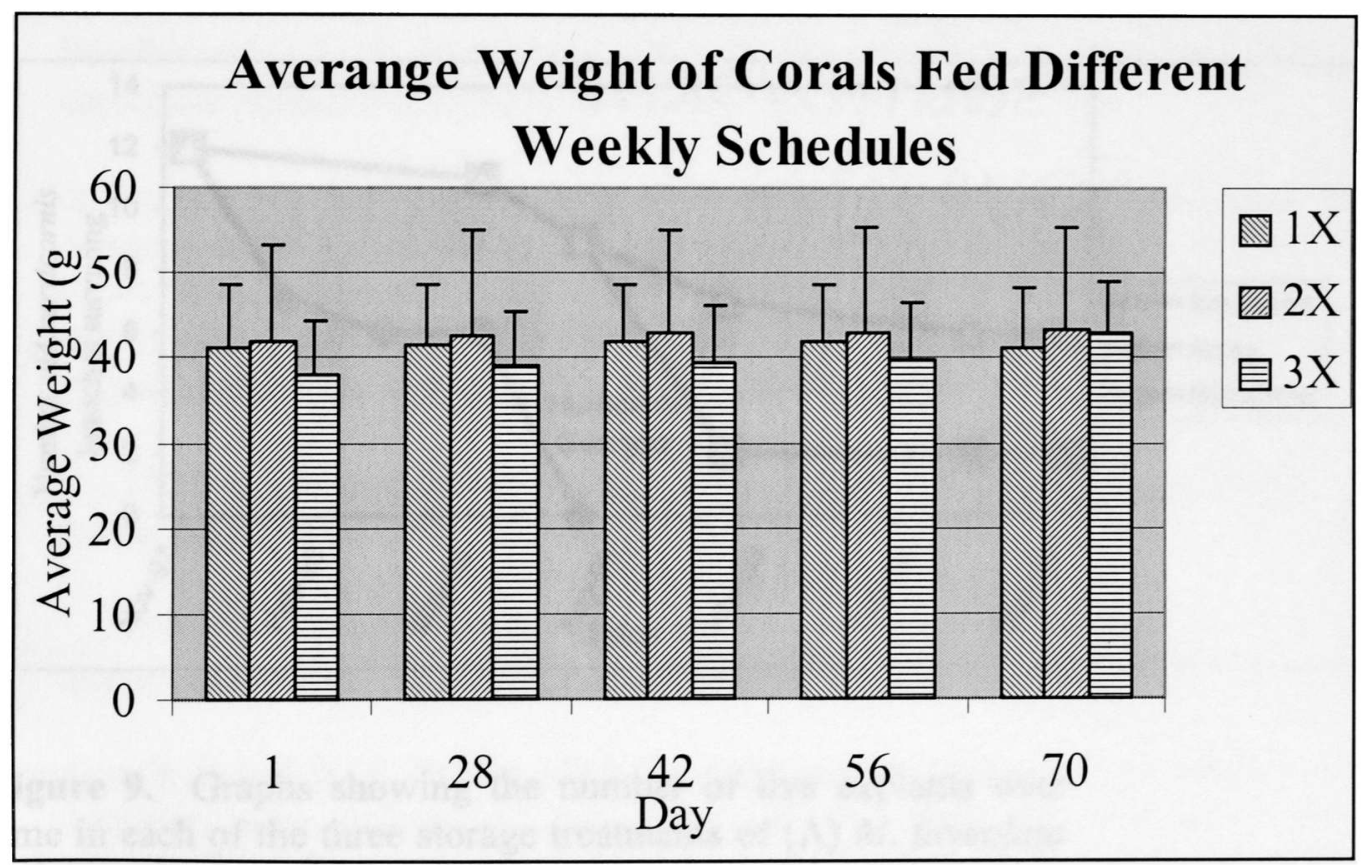

Figure 8. Graphs of the weights of the $M$. faveolata explants during the feeding experiment. 


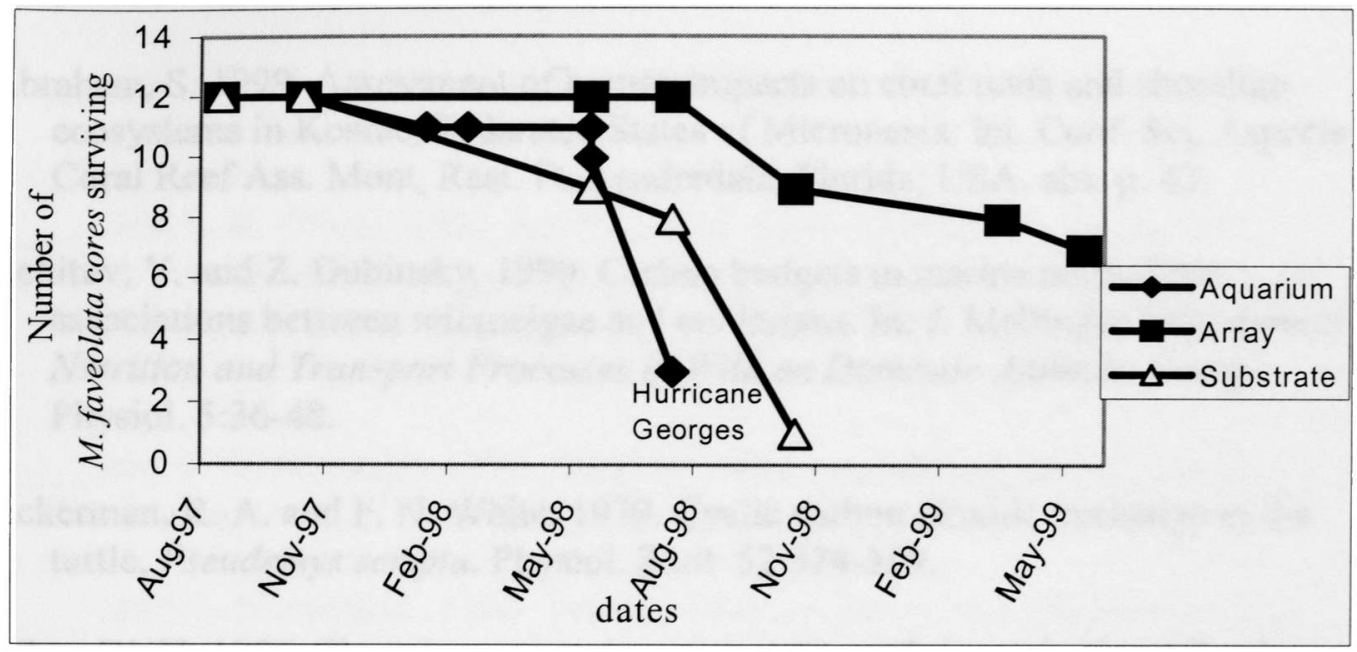

B

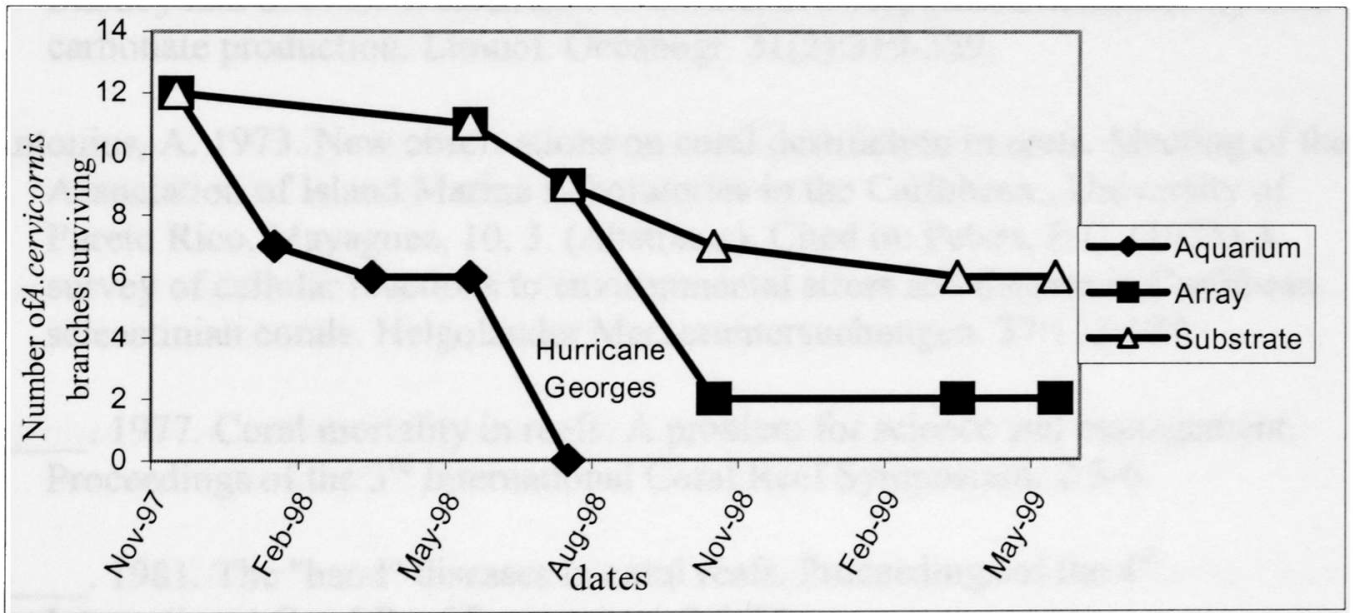

Figure 9. Graphs showing the number of live explants over time in each of the three storage treatments of (A) $M$. faveolata and (B) A. cervicornis. 


\section{LIST OF REFERENCES}

Abdel-Salam, H. A. and J. W. Porter. 1988. Physiological effects of sediment rejection on photosynthesis and respiration in three Caribbean reef corals. Proc. $6^{\text {th }}$ Int. Coral Reef Symp. 2:285-292.

Abraham, S. 1999. Assessment of human impacts on coral reefs and shoreline ecosystems in Kosrae, Federated States of Micronesia. Int. Conf. Sci. Aspects Coral Reef Ass. Mont, Rest. Ft. Lauderdale, Florida, USA. abs. p. 43.

Achituv, Y. and Z. Dubinsky. 1990. Carbon budgets in marine mutualistic associations between microalgae and cnidarians. In: J. Mellinger (ed). Animal Nutrition and Transport Processes in Wild an Domestic Animals. Comp. Physiol. 5:36-48.

Ackerman, R. A. and F. N. White. 1979. Cyclic carbon dioxide exchange in the turtle, Pseudemys scripta. Physiol. Zool. 52:378-389.

Adey, W. H. 1983. The microcosm: A new tool for reef research. Coral Reefs 1:193-201.

Anderson, L. G., P. O. J. Hall, A. Iverfeldt, M. M. Rutgers van der Loeff, B. Sundby and S. F. G. Westerlund. 1986. Benthic respiration measured by total carbonate production. Limnol. Oceanogr. 31(2):319-329.

Antonius, A. 1973. New observations on coral destruction in reefs. Meeting of the Association of Island Marine Laboratories in the Caribbean., University of Pureto Rico, Mayaguez, 10, 3. (Abstracts). Cited in: Peters, E.C. (1984) A survey of cellular reactions to environmental stress and disease in Caribbean scleactinian corals. Helgolander Meeresuntersuchungen. 37:113-137.

. 1977. Coral mortality in reefs: A problem for science and management. Proceedings of the $3^{\text {rd }}$ International Coral Reef Symposium. 2:3-6.

. 1981. The "band" diseases in coral reefs. Proceedings of the $4^{\text {th }}$ International Coral Reef Symposium. 2:6-14.

Aronson R. B and W. F. Precht. 1999. Scales, hypotheses, and the limits of detection in the ecology and management of coral reefs. Int. Conf. Sci. Aspects Coral Reef Ass. Mont, Rest. Ft. Lauderdale, Florida, USA. abs. p. 49.

Aronson, R. B. and D. W. Swanson. 1997. Video surveys of carol reefs: uni- and multi- variate applications. Proc. $8^{\text {th }}$ Int. Coral Reef Symp., Panama 14411446. 
Bak, R. P. M. 1978. Lethal and sublethal effects of dredging on reef corals. Mar. Poll. Bull. 9:14-16.

1983. Neoplasia, regeneration and growth in reef building coral Acropora palmata. Mar. Biol. 77:221-227.

. and J. B. H. W. Elgershuizen. 1976. Patterns of oil-sediment rejection in corals. Mar. Biol. 37:105-113.

. and S. R. Criens. 1981. Survival after fragmentation of colonies of Madracis mirabilis, Acropora palmata and A. cervicornis (Scleractinia) and the subsequent impact of a coral disease. Proc. $4^{\text {th }}$ Intl. Coral Reef Symp. 2:221-227.

and E. H. Meesters. 1996. Coral diversity, populations and ecosystem functioning. Proc. $6^{\text {th }}$ Intl. Conf. Coelent. Biol.

. and G. Nieuwland. 1994. Twenty years of change in coral communities over deep reef slopes along leeward coasts in the Netherlands Antilles. Bull. Mar. Sci. 56: 609-619.

and Y. Stewart-van Es. 1980. Regeneration of superficial damage in the scleractinian corals Agaricia agaricities f. purpurea and Porites astreoides. Bull. Mar. Sci. 30:883-887.

and G. Van Eys. 1975. Predation of the sea urchin Diadema antillarum Philippi on living coral. Oecologia. 20:111-115.

Barnes, H. and M. Barnes. 1957. Resistance of desiccation in intertidal barnacles. Science. 126:358.

Barnhart, M. C. 1986a. Respiratory gas tensions and gas exchange in active and dormant land snails, Otala lactea. Physiol. Zool. 59:733-745.

. 1986b. Control of acid-base status in active and dormant land snails, Otala lactea (Pulmanata, Helicidae). J. Comp. Physiol. 156:347-354.

Barnhart, M. C. and B. R. McMahon. 1987. Discontinuous carbon dioxide release and metabolic depression in dormant land snails. J. Exp. Biol. 128:123-138.

Becker, L. C. and E. Mueller. In Press. The culture, transplantation, and storage of Montastraea faveolata, Acropora cervicornis, and A. palmata: What we have learned so far. Bull. Mar. Sci. 
Bickler, P. E. 1984. $\mathrm{CO}_{2}$ balance of a heterothermic rodent: comparison of sleep, torpor and awake states. Am. J. Physiol. 246 (Reg. Int. Comp. Physiol.

15):R49-R55.

Birthisel B., S. Yoder and J. Kurtz. 1999. Adventures in aquaculture at "TerraSubAqua". Int. Conf. Sci. Aspects Coral Reef Ass. Mont, Rest. Ft. Lauderdale, Florida, USA. abs. p.56.

Borneman E. H. and J. Lowrie. 1999. Advances in captive husbandry and propagation: An easily utilized reef replenishment means from the private sector? Int. Conf. Sci. Aspects Coral Reef Ass. Mont, Rest. Ft. Lauderdale, Florida, USA. abs. p. 58-59.

Bouchon, C., Jaubert, J. and Bouchon-Navaro, Y. 1981. Evolution of a semiartificial reef built by transplanting coral heads. Tethys. 10:173-176.

Bowden-Kerby, A. 1996. The Response of Acropora corals to transplanting: preliminary results from Micronesia and Puerto Rico. Manuscript draft presented at $8^{\text {th }}$ Intl. Coral Reef Symp., Panama.

. 1999a. The "Johnny Coral Seed" approach to coral reef restoration: New methodologies appropriate for lower energy reef areas. Int. Conf. Sci. Aspects Coral Reef Ass. Mont, Rest. Ft. Lauderdale, Florida, USA. abs. p. 59.

1999b. The community coral reef initiative: Coral reef restoration in rural Pacific island settings. Int. Conf. Sci. Aspects Coral Reef Ass. Mont, Rest. Ft. Lauderdale, Florida, USA. abs. p. 59.

Branch, G. M., P. Borchers, C. R. Brown, and D. Donnelly. 1988. Temperature and food as factors influencing oxygen consumption of intertidal organisms, particularly limpets. Am. Zool. 28:137-146.

Brown, B. E. 1987. Worldwide death of coral-Natural cylical events or man-made pollution? Mar. Poll. Bull. 18(1):9-13.

Brown, E., E. F. Cox, B. Tissot, K. Rodgers and W. Smith. 1999. Evaluation of benthic sampling methods considered for the Coral Reef Assessment and Monitoring Program (CRAMP) in Hawaii. Int. Conf. Sci. Aspects Coral Reef Ass. Mont, Rest. Ft. Lauderdale, Florida, USA. abs. p.61-62.

Brown, S. D. 1996. Captive propagation of scleractinian corals in closed system. (unpublished manuscript)

Bruckner A. W. and R. J. Bruckner. 1999. Rapid assessment of coral reef condition and short-term changes to corals affected by disease in Curaçao, 
Netherlands Antilles. Int. Conf. Sci. Aspects Coral Reef Ass. Mont, Rest. Ft. Lauderdale, Florida, USA. abs. p. 62.

Burton, R. F. 1976. Calcium metabolism and acid-base balance in Helix pomatia. In: P. S. Davies (ed). Perspectives in Experimental Biology, vol. 1. 7-16.

Bythell, J. C., E. H. Gladfelter and M. Bythell. 1993. Chronic and catastrophic natural mortality of three common Caribbean reef corals. Coral Reefs. 12:143152.

Call, K. A. 1999. Coral reef habitat mapping: Using satellite remote sensing and optical spectra data. Int. Conf. Sci. Aspects Coral Reef Ass. Mont, Rest. Ft. Lauderdale, Florida, USA. abs. p.64.

Carlson, B. A. 1987. Aquarium systems for living corals. Int. Zoo. Yb. 26:1-9. 1999. Organism responses to rapid change: What aquaria tell us about nature. Amer. Zool. 39:44-55.

Carlton, R. G. and L. L. Richardson. 1995. Oxygen and sulfide dynamics in a horizontally migrating cyanobacterial mat: Black band disease of corals. FEMS Microbiol. Eco. 18:155-162.

Castro, C. B. 1999. Brazillia Reefs: What we already know and what is still missing. Int. Conf. Sci. Aspects Coral Reef Ass. Mont, Rest. Ft. Lauderdale, Florida, USA. abs. p. 65.

Chalker, B. E. 1981. Simulating light-saturation curves for photosynthesis and calcification by reef-building corals. Mar. Biol. 63:135-141.

Chalker, B. E., W. C. Dunlap and J. K. Oliver. 1983. Bathymetric adaptations of reef-building corals at Davies Reef, Great Barrier Reef, Australia. II. Light saturatio curves for photosynthesis and respiration. J. Exp. Mar. Biol. Ecol. 73:37-56.

Chavez, E. A., E. Hidalgo and M. A. Izaguirre. 1985. A comparative analysis of Yucatan coral reefs. $5^{\text {th }}$ Intl. Coral Reef Symp., Tahiti. 355-361.

Chiappone, M. and K. M. Sullivan Sealey. 1999. Ref and hard-bottom habitat distribution in the central Bahamas: Implications for marine reserve design. Int. Conf. Sci. Aspects Coral Reef Ass. Mont, Rest. Ft. Lauderdale, Florida, USA. abs. p.68.

Churchill, T. A. and K. B. Storey. 1989. Intermediary energy metabolism during dormancy and anoxia in the land snail Otala lactea. Physiol. Zool.

62(5):1015-1030. 
Clark, S. and A. J. Edwards. 1994. Use of artificial reef structures to rehabilitate reef flats degraded by coral mining in the Maldives. Bull. Mar. Sci. 55(23):724-744.

Clark, T. 1996. Tissue regeneration rate of coral transplants in a wave exposed environment, Cape D'Aguilar, Hong Kong. Proc. $8^{\text {th }}$ Int. Coral Reef Symp., Panama. 2069-2074.

Coles, S. L. 1969. Quantitative estimates of feeding and respiration for three scleractinian corals. Limnol. Oceanogr. 14:949-953

. and P. L. Jokiel. 1977. Effects of Temperature on photosynthesis and respiration in hermatypic corals. Mar. Biol. 43:209-216.

Cook, C. B., E. M. Mueller, E. Annis and M. D. Ferrier. 1999. Influence of Florida Bay water on the reef coral Montastraea faveolata I. Coral growth. Coral Reefs. (submitted).

Croquer, A, E. Villamizar and N. Noriega. 1999. Tissue regeneration of the reef building coral Montastraea anularis, in two coralline patches at Dos Mosquises Key, Los Roques National Park, Venezuela. Int. Conf. Sci. Aspects Coral Reef Ass. Mont, Rest. Ft. Lauderdale, Florida, USA. abs. p.75.

Curtis, C. 1985. Investigating reef recovery following a freighter grounding in the Key Largo National Marine Sanctuary (Florida Keys, USA). Proc. $5^{\text {th }}$ Intl. Coral Reef congress. Tahiti. 6:471-476.

Davies, P. S. 1980. Respiration in some Atlantic reef corals in relation to vertical distribution and growth form. Biol. Bull. 158:187-194.

. 1984. The role of zooxanthellae in the nutritional energy requirements of Pocillopora eydouxi. Coral Reefs. 2:181-186.

Davies, P. S. 1989. Short-term growth measurements of corals using an accurate buoyant weighing technique. Mar. Bio. 101:389-395.

Delbeek, J. and J. Sprung. 1994. The Reef Aquarium, a comprehensive guide to the identification and care of tropical marine invertebrates. Ricordea Publishing, Coconut Grove, Florida.

Dejours, P. 1981. Principles of Comparative Respiratory Physiology. $2^{\text {nd }}$ edition. Amsterdam. Elsevier North-Holland.

Dennison, W. C. and D. J. Barnes. 1988. Effect of water motion on coral photosynthesis and calcification. J. Exp. Mar. Biol. Ecol. 115:67-77. 
Dodge, R. E., R. C. Allen and J. Thomson. 1974. Coral growth related to resuspension of bottom sediments. Nature. 247:574-577.

Dodge, R. E., S. C. Wyers, H. R. Frith, A. H. Knap, S. R. Smith, C. B. Cook and T. B. Sleeter. 1984. Coral calcification rates by buoyant weight technique: effects of alizarin staining. J. Exp. Mar. Biol. Ecol. 75:217-232.

. and Szmant, A. 1985. Effects of drilling fluids on reef corals: a review. In: Duedall, I.W. Kester, D.R. Park, P.K. and Ketchum, B.H. (eds). Wastes in the ocean, 4: Energy wastes. Wiley Interscience.

., D. Anderegg, R. Fergen and P. Cooke. 1999. Coral transplantation following repair of outfall. Int. Conf. Sci. Aspects Coral Reef Ass. Mont, Rest. Ft. Lauderdale, Florida, USA. abs. p.80.

Dokken Q. R., J. W. Tunnell, I. R. MacDonald and C. R. Beaver. 1999. Long term monitoring and assessment of the Flower Garden Banks coral ecosystem. Int. Conf. Sci. Aspects Coral Reef Ass. Mont, Rest. Ft. Lauderdale, Florida, USA. abs. p. 81 .

Ducklow, H. and R. Mitchell. 1979a. Observations on naturally and artificially diseased tropical corals: A scanning electron microscope study. Microbial Ecol. 5:215-223. . and _ 1979b. Composition of mucus released by coral reef coelenterates. Limn. Oceanogr. 19:810-814.

Dustan, P. 1977. Vitality of reef coral populations off Key Largo, Florida: Recruitment and mortality. Env. Geo. 2:51-58. . and J. C. Halas, 1987. Changes in the reef-coral community of Carysfort Reef, Key Largo, Florida: 1974 to 1982. Coral Reefs. 6:91-106.

Edmunds, P. J. and P. S. Davies. 1988. Post-illumination stimulation of respiration rate in the coral Porites porites. Coral Reefs. 7:7-9

Edney, E. B. 1978. Water Balance In Land Arthropods. New York. SpringerVerlag.

Edward, A. 1999. Coral reef and coastal resource use in Micronesia. Int. Conf. Sci. Aspects Coral Reef Ass. Mont, Rest. Ft. Lauderdale, Florida, USA. abs. p.83.

Elgershuizen, J. H. B. W. and de Kruijf, H.A.M. 1976. Toxicity of crude oils and a dispersant to the stony coral Madracis mirabilis. Mar. Poll. Bull. 7:22-25. 
Faure, G., N. Conruyt, M. Pichon, M. Guillaume, D. Grosser and Y. Geynet. 1999. Development of a knowledge base for the corals of the Mascarene Archipelago and applications to coral reef management. Int. Conf. Sci. Aspects Coral Reef Ass. Mont, Rest. Ft. Lauderdale, Florida, USA. abs. p.85.

Fishelson, L. 1973. Ecology of coral reefs in the Gulf of Aqaba (Red Sea) influenced by pollution. Oecologia. 12:55-67.

Fisher L. E. and K. Banks. 1999. Permanent reef community monitoring sites offshore of Broward County, Florida: Preliminary comparative results. Int. Conf. Sci. Aspects Coral Reef Ass. Mont, Rest. Ft. Lauderdale, Florida, USA. abs. p.87.

Franzisket, L. 1970. The atrophy of hermatypic reef corals maintained in darkness and their subsequent regeneration in light. Int. Revue ges. Hydrobiol. Hydrogr. 55:1-12.

Fucik, K. W., T. J. Bright and K. S. Goodman, 1984. Measurements of damage, recovery, and rehabilitation of coral reefs exposed to oil. In: Cairne, J. and Buikema, A. L. (eds). Restoration of habitats impacted by oil spills. Butterworth, Boston.

Galzin, R. 1981. Effects of coral sand dredging on fish fauna in the Lagoon of the "Grand Cul de Sac Marin, Guadeloupe - French West Indies". $4^{\text {th }}$ Intl. Coral Reef Symp., Manila. P. 115.

Garcia, R. U., E. M. Alvarado and A. Acosta. 1996. Regeneration of colonies and transplants of Acropora palmata in the National Park Corales del Rasario, Colombian Caribbean. Abstract from $8^{\text {th }}$ Intl. Coral Reef Symp., Panama.

Garzón-Ferreira, J, A. Rodríguez, D. L. Gil-Agudelo and M. F. Gil-Navia. 1999. Launching SIMAC: The national monitoring system for the coral reefs of Colombia. Int. Conf. Sci. Aspects Coral Reef Ass. Mont, Rest. Ft. Lauderdale, Florida, USA. abs. p.90.

Gil-Navia, M. F., J. A. Sánchez and E. Alvarado. 1999. Transplantation of reefbuilding corals on the Rosario Archipelago, Colombian Caribbean. Int. Conf. Sci. Aspects Coral Reef Ass. Mont, Rest. Ft. Lauderdale, Florida, USA. abs. p.91.

Ginsburg, R., P. Kramer, J. Lang, P. Sale and R. Steneck. 1999. Rapid assessment of corals, algae, and fish on reefs of the western Atlantic and Gulf of Mexico (AGRRA). Int. Conf. Sci. Aspects Coral Reef Ass. Mont, Rest. Ft. Lauderdale, Florida, USA. abs. p.92. 
Gladfelter, W. B. 1982. White-band disease in Acorpora palmata: Implications for the structure and growth of shallow reefs. Bull. Mar. Sci. 32(2):639-643.

, R.K. Monahan, J. C. Ogden and R. F. Dill. 1977. Coral Destruction. In: Environmental Studies of Buck Island Reef National Monument, U.S. National Park Service Report, pp. XI-1-7.

Glass, M. L. and K. Johansen. 1979. Periodic breathing in the crocodile, Crocodylus niloticus: Consequences for the gas exchange ratio and control of breathing. J. Exp Zool. 208:319-326.

Gleason, D.F. and D. A. Brazeau. 1999. Can selfing coral species be used to enhance restoration of damaged reefs? Int. Conf. Sci. Aspects Coral Reef Ass. Mont, Rest. Ft. Lauderdale, Florida, USA. abs. p.92-93.

Gleason, M. G.. 1999. The importance of algal-grazer interactions in early growth and survivorship of sexual recruits and transplanted juvenile corals. Int. Conf. Sci. Aspects Coral Reef Ass. Mont, Rest. Ft. Lauderdale, Florida, USA. abs. p.93.

Glynn, P. W. 1988. Corallivore population sizes and feeding effects following El Niño (1982-1983)-associated coral mortality in Panama. Proc. $5^{\text {th }}$ Intl. Coral Reef Congr. 4:183-187.

Goenaga, C. 1991. The state of coral reefs in the wider Caribbean. Inteciencia. 16(1):12-20.

Goodlett, R. O. 1983. The Smithsonian living coral reef exhibit. AAZPA. 552556.

Goreau, T. F. 1959. The ecology of Jamacan coral reefs I. Species composition and zonation. Ecol. (40)1:67-90.

Goreau, T. J. and W. Hilbertz, 1996. Reef restoration using sea water electrolysis in Jamaica. Abstract from $8^{\text {th }}$ Intl. Coral Reef Symp., Panama.

Graham B. D. and P. S. Fitzgerald. 1999. New technique for hard coral reattachment field-tested following two recent ship groundings. Int. Conf. Sci. Aspects Coral Reef Ass. Mont, Rest. Ft. Lauderdale, Florida, USA. abs. p.9596.

Guzman, H. 1991. Restoration of coral reefs in Pacific Costa Rica. Cons. Bio. 5(2):189-195. 
Harriott, V. J. and D. A. Fisk, 1988. Coral transplantation as a reef management option. Proc. 6th Intl. Coral Reef Symp. 2:375-379.

Harrison, P. L. and C. C. Wallace. 1990. Reproduction, dispersal and recruitment of scleractinian corals. In: Dubinsky, Z. (ed). Coral Reefs. Elsevier, New York.

Haskell, B. D. 1999. Monitoring changes in ecosystem structure and fuction in no-take zones in the Florida Keys National Marine Sactuary. Int. Conf. Sci. Aspects Coral Reef Ass. Mont, Rest. Ft. Lauderdale, Florida, USA. abs. p.99.

Helmuth, B. and K. Sebens. 1993. The influence of colony morpholgy and orientation to flow on particle capture by the scleatcinian coral Agaricia agaricites. J. Exp. Mar. Biol. Ecol. 165:251-278.

Hermes-Lima, M., J. M. Storey and K. B. Storey. 1998. Antioxidant defenses and metabolic depression: The hypothesis of preparation for oxidative stress in land snails. Comp. Biochem. Physiol. Part B. 120:437-448.

Herreid II, C. F. 1977. Metabolism of land snails (Otala lactea) during dormancy, arousal, and activity. Phyiol. 56A:211-215.

Hicks, J. W. and M. L. Riedesel. 1983. Diurnal ventilatory patterns in the garter snake, Thamnophis elegans. J. Comp. Physiol. 149:503-510.

Hodgson, G. 1999. Using Reef Check to monitor coral reefs. Int. Conf. Sci. Aspects Coral Reef Ass. Mont, Rest. Ft. Lauderdale, Florida, USA. abs. p.105.

Holden, H. and E. F. LeDrew. 1999. A data base of 334 reflectance spectra enables identification of broad categories of coral reef features. Int. Conf. Sci. Aspects Coral Reef Ass. Mont, Rest. Ft. Lauderdale, Florida, USA. abs. p.106.

Hourigan, T.. 1999. A marine "gap-analysis" framework for the assessment and monitoring of U. S. coral reefs. Int. Conf. Sci. Aspects Coral Reef Ass. Mont, Rest. Ft. Lauderdale, Florida, USA. abs. p.106-107.

Howard, L. S. and B. E. Brown, 1984. Heavy metals and reef corals. Oceanogr. Mar. Biol. Ann. Rev. 22:195:210.

Hudson, J. H. 1981. Response of Montastraea annularis to environmental change in the Florida Keys. Proc. $4^{\text {th }}$ Intl. Coral Reef Symp., Manila, 2:233-240. 
Hudson, J. H. and R. Diaz. 1988. Damage survey and restoration of M/V Wellwood grounding sites, Molasses Reef, Key Largo National Marine Sanctuary, Florida. Proc. $6^{\text {th }}$ Intl. Coral Reef Symp., Australia. 2:231-236. ., D. M. Robbin, J. T. Tilman and J. L. Wheaton, 1989. Building a coral reef in Southeast Florida: combining technology and aesthetics. U.S. Geological Survey, Fisher Island Station, Miami Beach, Florida 33139.

. and W. B. Goodwin, 1996. Restoration and growth rate of hurricane damaged pillar coral (Dendrogyra cylindrus) in the Key Largo National Marine Sanctuary, Florida. Abstract from $8^{\text {th }}$ Intl. Coral Reef Symp., Panama.

Hughes, T. P. 1994. Catastrophes, phase shifts, and large-scale degradation of a Caribbean coral reef. Science. 265:1547-1551.

Idechong N. 1999. Community-based efforts for protecting Palau's coral reef resources. Int. Conf. Sci. Aspects Coral Reef Ass. Mont, Rest. Ft. Lauderdale, Florida, USA. abs. p.109.

Idjadi, J. A. and P. J. Edmunds. 1999. A preliminary study of the effects of twostroke engine exhaust and coolant effluet on the skeletal growth of the scleractinian, Madracis mirabilis. Int. Conf. Sci. Aspects Coral Reef Ass. Mont, Rest. Ft. Lauderdale, Florida, USA. abs. p.109-110.

Iliff, J. W., W. B. Goodwin, J. H. Hudson, M. W. Miller and J. Timber. 1999. Emergency stabilization of Acropora palmata with stainless steel wire and nails: Impressions, lessons learned, and recommendations from Mona Island, Puerto Rico. Int. Conf. Sci. Aspects Coral Reef Ass. Mont, Rest. Ft. Lauderdale, Florida, USA. abs. p. 110.

Jaap, W. 1999. Scleractinia coral dynamics at three reefs in Dry Tortugas National Park, Florida, USA, 1989-1997. Int. Conf. Sci. Aspects Coral Reef Ass. Mont, Rest. Ft. Lauderdale, Florida, USA. abs. p.111-112.

., Graham, B. and G. Mauseth, 1996. Reattaching corals using epoxy cement. Abstract from $8^{\text {th }}$ Intl. Coral Reef Symp., Panama. page 98.

Jaubert, J. 1989. An integrated-denitrifying biological system capable of purifying sea water in a closed circuit aquarium. Bull. Inst. Ocean. 5:101-106.

. and P. Coromandel. 1991. System for biological purification of water containing organic materials and derivative products. Patent \# 4,995,980. 18 pages. 
., M. Marchioretti, N. Ounais, P. Gilles, F. Priouzeau and E. Tambutte. 1996. Potential use of cultured coral transplants in aquarium stocking and reef restoration, 4th Intl. Aquar. Congr., Tokyo

Johannes, R. E. 1974. Sources of nutritional energy for reef corals. Proc. $2^{\text {nd }}$ Int. Symp. Coral Reefs. 1:133-138.

., 1975. Pollution and degradation of coral reef communities. In: Ferguson Wood, E. J., Johannes, R. E. (eds) Trop. Mar. Poll.. Elsevier Scientific Publ., New York. p. 13-51.

Johnson, A. S. and K. P. Sebens. 1993. Consequences of a flattened morphology: effects of flow on feeding rates of the scleractinian coral Meandrina meandrites. Mar. Ecol. Prog. Ser. 99:99-114.

Johnson, D. H. 1992. Synchronous planulation of Manicina areolata (Scleractinia) with lunar periodicity. Mar. Ecol. Prog. Ser. 87:265-273.

Jokiel, P. L., J. E. Maragos and L. Franzisket. 1978. Coral growth: buoyant weight technique. Pages 529-541 in: D. R. Stoddart and R. E. Johannes, (eds.) Coral reefs: Research methods. Monographs on oceanographic methodology. UNESCO, Paris.

Knowlton, N., J. C. Lang, M. C. Rooney and P. Clifford, 1981. When hurricanes kill corals: evidence for delayed mortality in Jamaican staghorns. Nature. 294:251-252.

, and 1981. Evidence of delayed mortality in hurricanedamaged Jamaican staghorn corals. Nature. 294:251-252.

. Weil, L. A. Weigt and H. M. Guzman. 1992. Sibling species in Montastraea annularis, coral bleaching and the coral climate record. Science. 255:330-334.

L. Maté, H. M. Guzmán and R. Rowan. 1997. Direct evidence for reproductive isolation among the three species of the Montastraea annularis complex in Central America (Panamá and Honduras). Mar. Biol. 127:705711 .

Le Tissier, M. A. and B. E. Brown. 1999. Natural and antropogenic disturbances on intertidal reefs of S. E. Phuket Thailand. Int. Conf. Sci. Aspects Coral Reef Ass. Mont, Rest. Ft. Lauderdale, Florida, USA. abs. P.123-124.

Leletkin, V. A., E. G. Nechai and É. A. Titlyanov. 1993. Respiration rate of zooxanthellae in a native coral. Russian J. Mar. Biol. 19(5-6):340-345. 
Lewis, D. H. and D. C. Smith. 1971. The autotrophic nutrition of symbiotic marine coelenterates with special reference to hermatypic corals. I. Movement of photosynthetic products between the symbionts. Proc. R. Soc. B. 178:111192.

Lindahl, U. 1998. Low-tech rehabilitation of degraded coral reefs through transplantation of staghorn corals. Ambio. 27(8):645-650.

Lopez, J. and N. Knowlton, 1997. Descrimination of species in the Montastraea annularis complex using multiple genetic loci. Proc. 8th Intl. Coral Reef Symp. 2:1613-1618.

Maragos, J. E. 1974. Coral transplantation: A method to create, preserve, and manage coral reefs. Sea Grant Advisory Report UNIHI-SEAGRANT-AR-7403. pp. 30.

McClanahan, T. R. 1997. Primary succession of coral-reef algae: Differing patterns on fished versus unfished reefs. J. Exp. Mar. Biol. Ecol. 218:77-102.

McCloskey, L. R. and L. Muscatine. 1984. Production and respiration in the Red Sea coral Stylophora pistillata as a function of depth. Proc. R. Soc. Lond. B. 222:215-230.

, D. S. Wethey and J. W. Porter. 1978. Measurement and interpretation of photosynthesis and respiration in reef corals. In: D. R. Stoddart and R. E. Johannes (eds). Coral reefs: Research methods. UNESCO. 379-396.

Meesters, E.H. 1992. Effects of sedimentation and lesion position on coral tissue regeneration. Proc. $7^{\text {th }}$ Intl. Coral Reef Symp. 681-688.

., Bos, A. and G. J. Gast 1992. Effects of sedimentation and lesion position on coral tissue regeneration. Proc. $7^{\text {th }}$ Intl. Coral Reef Symp.

and R. P. M. Bak. 1993. Effects of coral bleaching on tissue regeneration potential and colony survival. Mar. Ecol. Prog. Ser. 96:189-198.

, I. Wesseling and R. P. M. Bak. 1996. Partial mortality in three species of reef-building corals (Scleractinia) and the relation with colony morphology. Bull. Mar. Sci. 58:838-852.

., I. Wesseling and R.P.M. Bak. 1997. Coral colony tissue damage in six species of reef-building corals: partial mortality in relation with depth and colony surface area. J. Sea Res. 37: 131-144. 
., W. Pauchli and R. P. M. Bak. 1997. Predicting maximum regeneration of physical damage on a reef building coral by regeneration capacity and lesion shape. Mar. Ecol. Prog. Ser. 146: 91-99

Miller, P. L. 1974. Respiration - aerial gas transport. In: M. Rockstein (ed). Physiology of the insecta, vol. 5. New York Academic Press. 345-402.

Miller, S. L., G. B. McFall and A. W. Hulbert, 1993. Guidelines and recommendations for coral reef restoration in the Florida Keys National Marine Sanctuary. Workshop report. National Oceanic and Atmospheric Administration, Sanctuary and Reserves Division. 38p.

Mingoa-Licuanan, S. S. 1993. Oxygen consumption and ammonia excretion in juvenile Tridacna gigas (Linne, 1758): effects of emersion. J. Exp. Mar. Biol. Ecol. 171:119-137.

Munoz-Chagin, R.F. 1996. Coral transplanting program in the Paraiso Coral Reef, Cozumel Island, Mexico. Manuscript from $8^{\text {th }}$ International Coral Reef Symposium, Panama. 2:2075-2078.

Muscatine, L. 1973. Nutrition of corals. O. A. Jones and R. Endean (eds) Biology and Geology of Coral Reefs, Vol. II. Academy Press, NY. 77-115.

and C. Hand. 1958. Direct evidence for transfer of materials from symbiotic algae to the tissues of a coelenterate. Proc. Natn. Acad. Sci. U.S. A. 44:1259-1263.

., L. R. McCloskey and R. E. Marian. 1981. Estimating the daily contributions of carbon form zooxanthellae to coral animal respiration. Limnol. Oceanogr. 26(4):601-611.

Muthiga, N. A. and A. M. Szmant. 1987. The effects of salinity stress on the rates of aerobic respiration and photosynthesis in the hermatypic coral Siderastrea siderea. Biol. Bull. 173:539-551.

Neudecker, S. 1981. Growth and survival of scleractinian coral exposed to thermal effluents at Guam. 4th Intl. Coral Reef Symp., Manila. 1:173-180.

NIH. 1999. http://www.scioncorp.com/frames/fr_download_now.htm

NOAA. 1999. http://www.sanctuaries.nos.noaa.gov/special/columbus/ columbus.html 
Oren, U. and Y. Benayahu. 1997. Transplantation of juvenile corals: a new approach for enhancing colonization of artificial reefs. Mar. Biol. 127:499505.

Patterson, M. R. 1985. The effects of flow on the biology of passive suspension feeders: Prey capture, feeding rate, and gas exchange in selected cnidarians. Ph. D. Thesis. Harvard University. 314.

Patterson, M. R., K. P. Sebens and R. R. Olson. 1991. In situ measurements of flow effects on primary production and dark respiration in reef corals. Limnol. Oceanogr. 36(5)936-948.

Pearson, R.G. 1981. Recovery and recolonization of coral reefs. Mar.Ecol. Progr. Ser. 4:105-122.

Peters, E.C. 1984. A survey of cellular reactions to environmental stress and disease in Caribbean scleactinian corals. Helgolander Meeresuntersuchungen. 37:113-137.

1993. Diseases of other invertebrate phyla: porifera, cnidaria, ctenophora, annelida, echinodermatata. In: J.A. Couch and J.W. Fournie (eds).

Pathobiology of marine and extuarian organism. CRC Press. Boca Raton, FL, USA. 393-449.

Peters, E.C. 1997. Diseases of coral-reef organisms. In: C. Birkland (ed). Life and death of coral reefs. Chapman and Hall Publ. 114-139.

., J. J. Oprandy and P. P. Yevich, 1983. Possible causal agent of "white band disease" in Caribbean acroporid corals. J. Invert. Pathol. 41:394-396.

Plucer-Rosario, G. and R. Randall, 1987. Preservation of rare coral species by transplantation and examination of their recruitment and growth. Bull. Mar. Sci. 41(2):585-593.

Porter, J. W. 1972. Patterns of species diversity in Caribbean reef corals. Ecology. $53: 745-748$.

., 1974. Zooplankton feeding by the Caribbean reef-building coral Montastrea cavernosa. Proc. $2^{\text {nd }}$ Intl. Coral Reef. Symp. 111-125.

. 1976. Autotrophy, heterotrophy, and resource partitioning in Caribbean reef-building corals. Am. Nat. 110:731-742.

and O. W. Meier, 1992. Quantification of loss and change in Floridian reef coral populations. Amer. Zool. 32:625-640. 
., L. Muscatine, Z. Dubinsky and P. G. Falkowski. 1984. Primary

production and photoadaptation in light- and shade-adapted colonies of the symbiotic coral, Stylophora pistillata. Proc. R. Soc. Lond. B. 222:161-180.

Precht, W. F., and R. B Aronson. 1997. Present status and future of reefs from the Caribbean biogeographic province. CSPG-SEPM Joint Convention, abstr.

Ramos-Flores, T. 1983. Lower marine fungus associated with black line disease in star corals (Montastea annularis, E. \& S.). Biol. Bull. 165:429-435.

Richardson, L.L. 1992. Red band disease: A new cyanobacterial infestation of corals. Proc. Underwater Sci. Sci. Diving Symp. 153-160. . 1996. Horizontal and vertical migration patterns of Phormidium corallyticum and Beggiatoa spp. associated with black-band disease of corals. Microbial Ecol. 32:323-335.

. 1997. Occurrence of the black band disease cyanobacterium on healthy corals on the Florida Keys. Bull. Mar. Sci. 61(2):485-490.

Richardson L.L., W.M. Goldberg, K.G. Kuta, R.B. Aronson,, G.W. Smith K.B. Ritchie, J.C. Halas, J.S. Feingold and S.M. Miller. 1998a. Florida's mystery coral-killer identified. Nature. 392:557- 558.

Richardson, L.L., W.M. Goldberg, R.G. Carlton and J.C. Halas. 1998b. Coral disease outbreak in the Florida Keys: Plague Type II. Revista de Biologia Tropical. 46 (Supl.5):187-198.

Rinkevich, B. 1995. Restoration strategies for coral reefs damaged by recreational activities: the use of sexual and asexual recruits. Rest. Ecol. 3(4):241-251.

. and Y. Loya, 1979. The reproduction of the Red Sea coral Stylophora pistillata. I. Gonads and planula. Mar. Ecol. Prog. Ser. 1:133-144.

Ritchie, K. B. and G. W. Smith. 1995. Preferential carbon utilization by surface bacterial communities from water mass, normal, and white-band diseased Acroporal cervicornis. Molec. Mar. Biol. and Biotech. 4(4), 345-352.

Rodriguez, A. 1981. Marine and coastal environmental stress in the wider Caribbean region. Ambio. 283-294.

Rogers, C.S. 1979. The effect of shading on coral reef structure and function. J. Exp. Mar. Biol. Ecol. 41:269-288. 
., Cintron, G. and C. Goenaga, 1978. The impact of military operation on the coral reefs of Vieques and Culebra. Report Submitted to the Department of Nartural Resources, Estado Libre Asociado de Puerto Rico. pp. 26.

Rogers, C. S. and N. H. Salesky. 1981. Productivity of Acorpora palmata (Larmark), macroscopic algae, and algal turf from Tague Bay Reef, St. Croix, U. S. Virgin Islands. J. Exp. Mar. Biol. Ecol. 49(2-3):179-187.

Romaine, S., E. Tambutté, D. Allemand and J. P. Gattuso. 1997. Photosynthesis, respiration and calcification of a zooxanthelate scleratinian coral under submerged and exposed conditions. Mar. Biol. 129:175-182.

Rutzler, K. and D. L. Santavy, 1983. The black band disease of Atlantic reef corals. I. Description of the cyanophyte pathogen. P.S.Z.N.I.: Mar. Ecol. 4:301-319.

Santavy, D. L. and E. C. Peters, 1997. Microbial pests: Coral disease in the western Atlantic. Proc. 8th Intl. Coral Reef Symp. 1:607-612.

Schauer, P. S., C. E. Olney and K. L. Simpson. 1979. Lipid level and fatty acid composition of Artemia cysts and newly hatched nauplii from five different locations. Intl. Symp. Brine Shrimp, Artemia salina. 113-114.

Sebens, K. P. 1987. Coelenterata. Chapter 3. In: F. J. Vernberg and T. J. Pandian (eds). Animal Energetics. Academic Press, New York. pp 55-120.

., 1997a. Zooplankton capture by reef corals: Corals are not plants! Reef Encounter. 21:10-15.

1997b. Adaptive responses to water flow: Morphology, energies, and distribution of reef corals. $8^{\text {th }}$ Int. Coral Reef Symp. 2:1053-1058.

., J. Witting and B. Helmuth. 1997. Effects of water flow and branch spacing on particle catpure by the reef coral Madracis mirablilis (Duchassaing and Michelotti). J. Exp. Mar. Biol. Ecol. 211:1-28.

Shephard, K. L. 1994. Functions of fish mucus. Rev. Fish. Biol. Fish. 4:401-429.

Shick, J. M. and J. A. Dykens, 1984. Photobiology of the symbiotic sea anemone Anthopleura elegantissima: photosynthesis, respiration and behavior under intertidal conditions. Biol. Bull. Mar. Biol. Lab. 166:608-619.

, J. Widdows and E Gnaiger. 1988. Calorimetric studies of behavior, metabolism and energetics of sessile intertidal animals. Am. Zool. 28:161-181. 
Shinn, E. A., J. H. Hudson, D. M. Robbin and B. Lidz. 1981. Spurs and grooves revisited: Construction versus erosion Looe Key Reef, Florida. Proc. $4^{\text {th }}$ Int. Coral Reef Symp., Manila.1:475-483.

Smith, G.W. and K. B. Ritchie, 1995. Bacterial studies on white-band disease of Acropora cervicornis. abstract from Eur. Meet. Intl. Soc. Reef Studies (ISRS).

Stoddard, D.R. 1969. Post-hurricane changes on the British Honduras reefs and cays: resurvey of 1965. Atoll Research Bull. 131:1-25.

1974. Post-hurricane changes on the British Honduras Reefs: re-survey of 1972. In: Cameron, A.M. et. al. (eds) Proc. $2^{\text {nd }}$ Intl. Symp. Coral Reefs. Great Barrier Reef Committee, Brisbane. 2:473-483.

Storey, K. B and J. M. Storey. 1990. Metabolic rate depression and biochemical adaptation in anaerobiosis, hibernation and estivation. Quat. Rev. Biol. 65(2):145-174.

Szmant, A. M. and N. J. Gassman, 1990. The effects of prolonged "bleaching" on the tissue biomass and reporduction of the reef coral Montastrea annularis. Coral Reefs. 8:217-224.

Szmant-Froelich, A. M., 1984. Effects of feeding frequency and symbiosis with zooxanthellae on nitrogen metabolism and respiration of the coral Astrangia danae. Mar. Biol. 81:153-162.

., Johnson, V. Hoehn, T.T., Battey, J., Smith, G.J., Fleishmann, E., Porter, J., Dallmeyer, D. 1981. the physiological effects of oil drilling muds on the Caribbean coral Montastrea annularis. 4th Intl. Coral Reef Symp., Manila. $1: 163-168$.

Telesnicki, G. J. and W. M. Goldberg. 1995. Effects of turbidity on the photosynthesis and respiration of two south Florida reef coral species. Bull. Mar. Sci. 57(2):527-539.

Thompson, J. H. and T. J. Bright, 1977. Effects of drill mud on sediment clearing rate of certain hermatypic corals. Proceedings Oil Spill Conference, New Orleans. American Petroleum Institute, Washington, D.C.

Tilman, D. and J. A. Downing, 1994. Biodiversity and stability in grasslands. Nature. 367:363-365.

van Duyl, F. C. 1983. The distribution of Acropora palmata and Acropora cervicornis along the coasts of Curacao and Bonaire, Netherlands Antilles. Paper read at Interdisciplinary Studies in Coral Reef Research, Annual Meeting of the International Society for Reef Studies, at Leiden, The 
Netherlands, December 1983. Cited in: Peters, E.C. 1993. Diseases of other invertebrate phyla: porifera, cnidaria, ctenophora, annelida, echinodermatata. In: J.A. Couch and J.W. Fournie (eds). Pathobiology of Marine and Extuarian Organism. CRC Press. Boca Raton, FL, USA. 393-449.

van Treeck, P. and H. Schuhmacher. 1997. Initial survival of coral nubbins transplanted by a new coral transplantation technology - options for reef rehabilitation. Mar. Ecol. Prog. Ser. 150:287-292.

Van Venghel, M. L. J. and R. P. M. Bak. 1994. Reproductive characteristics of the polymorphic Caribbean reef building coral Montastrea annularis. III Reproduction in damaged and regenerating colonies. Mar. Ecol. Prog. Ser. 109:229-233.

Williams, Jr., E.H. and L. Bunkley-Williams, 1990. The world-wide coral reef bleaching cycle and related soures of coral mortality. Atoll Research. Bull. 335:1-71.

Woodley et al 1981. Hurricane Allen's impact on Jamaican reefs. Science. 214:749-755.

Yap, H. T. and Gomez, E .D. 1984. Growth of Acropora pulchra. II. Response of natural and transplanted colonies to temperature and day length. Mar. Biol. 81:209-215.

and . 1985. Growth of Acropora pulchra. III. Preliminary observations on the effects of transplantation and sediment on the growth and survival of transplants. Mar. Biol. 87:203-209.

., P. M. Alino and E. D. Gomez. 1992. Trends in growth and mortality of 3 coral species (Anthozoa: Scleractinia), including effects of transplantation. Mar. Eco. Prog. Ser.83:91-101.

Yates, K. R. and Carlson, B.E. 1993. Corals in aquariums: how to use selective collecting and innovative husbandry to promote coral conservation.. In: Richmond, R.H. (ed) Proc. $7^{\text {th }}$ Intl. Coral Reef Symp., Guam.

Yonge, C. M. 1968. Living corals. Proc. Roy. Soc. Ser. B. 169:329-344. . and A. G. Nicholls. 1931. Studies on the physiology of corals. V. The effect of starvation in light and in darkness on the relationship between corals and zooxanthellae. Sci. Rep. Great Barrier Reef Expedition. 1:177-211. 